OPEN ACCESS

Edited by:

Jun Ge,

Tsinghua University, China

Reviewed by:

Anwar Sunna,

Macquarie University, Australia

Noha M. Mesbah,

Suez Canal University, Egypt Xiaoling Wu,

South China University of Technology,

China

Luis H. Alvarez,

Instituto Tecnológico de Sonora

(ITSON), Mexico

*Correspondence:

Ana Beloqui

ana.beloquie@ehu.eus

tThese authors share first authorship

Specialty section:

This article was submitted to

Bioprocess Engineering,

a section of the journal

Frontiers in Bioengineering and

Biotechnology

Received: 21 April 2020

Accepted: 29 June 2020

Published: 30 July 2020

Citation:

Rodriguez-Abetxuko A

Sánchez-deAlcázar D, Muñumer $P$ and Beloqui $A$ (2020) Tunable

Polymeric Scaffolds for Enzyme Immobilization.

Front. Bioeng. Biotechnol. 8:830. doi: 10.3389/fbioe.2020.00830

\section{Tunable Polymeric Scaffolds for Enzyme Immobilization}

\author{
Andoni Rodriguez-Abetxuko ${ }^{1+}$, Daniel Sánchez-deAlcázari't, Pablo Muñumer ${ }^{2}$ and \\ Ana Beloqui ${ }^{2,3,4 *}$
}

' Nanomaterials Group, BRTA, CIC nanoGUNE, San Sebastián, Spain, ${ }^{2}$ PolyZymes group, POLYMAT and Department of Applied Chemistry (UPV/EHU), San Sebastián, Spain, ${ }^{3}$ Department of Applied Chemistry, University of the Basque Country, San Sebastián, Spain, ${ }^{4}$ IKERBASQUE, Bilbao, Spain

The number of methodologies for the immobilization of enzymes using polymeric supports is continuously growing due to the developments in the fields of biotechnology, polymer chemistry, and nanotechnology in the last years. Despite being excellent catalysts, enzymes are very sensitive molecules and can undergo denaturation beyond their natural environment. For overcoming this issue, polymer chemistry offers a wealth of opportunities for the successful combination of enzymes with versatile natural or synthetic polymers. The fabrication of functional, stable, and robust biocatalytic hybrid materials (nanoparticles, capsules, hydrogels, or films) has been proven advantageous for several applications such as biomedicine, organic synthesis, biosensing, and bioremediation. In this review, supported with recent examples of enzyme-protein hybrids, we provide an overview of the methods used to combine both macromolecules, as well as the future directions and the main challenges that are currently being tackled in this field.

\footnotetext{
Keywords: enzyme-polymer hybrids, enzyme immobilization, polymeric supports, biocatalysis, nanocarriers, stabilization of enzymes
}

\section{INTRODUCTION}

The relevance of enzymes comprises numerous chemical processes in Nature, as they are the main actors in the metabolic machinery of each single organism. Moreover, enzymes are used in many industries and biotechnological applications due to their high efficiency, specificity, selectivity, and the possibility to carry out processes under the premises of Green Chemistry (Adrio and Demain, 2014). Unfortunately, the use of enzymes often presents several drawbacks, as they lose their functionality under those working conditions beyond their natural environment. Thus, enzymes can undergo denaturation throughout chemical degradation, physical unfolding, and aggregation caused by temperature or $\mathrm{pH}$ variations, organic solvents, or even the action of other enzymes (Balcão and Vila, 2015). In the last years, the formation of active and stable biocatalysts has been sought using assorted approaches, either through the alteration of the primary structure of the enzyme (i.e., rational design and directed evolution), by the immobilization of the enzyme on solid supports, through the chemical modification of the sequence of the protein, or by using combined approaches (Chapman and Stenzel, 2019). Molecular approaches, including computational modeling and structural biology, enable the modification of the active site or substrate/product channels within the enzyme, pursuing an enhancement of its bioactivity and stability (Beloqui and Cortajarena, 2020). Many of highly stable and genetically engineered enzymes are summarized in previous reviews (Arnold, 2018; Liu Q. et al., 2019). However, in this work, we tackle the use of polymeric scaffolds for the immobilization, protection, and stabilization of catalytic proteins. 


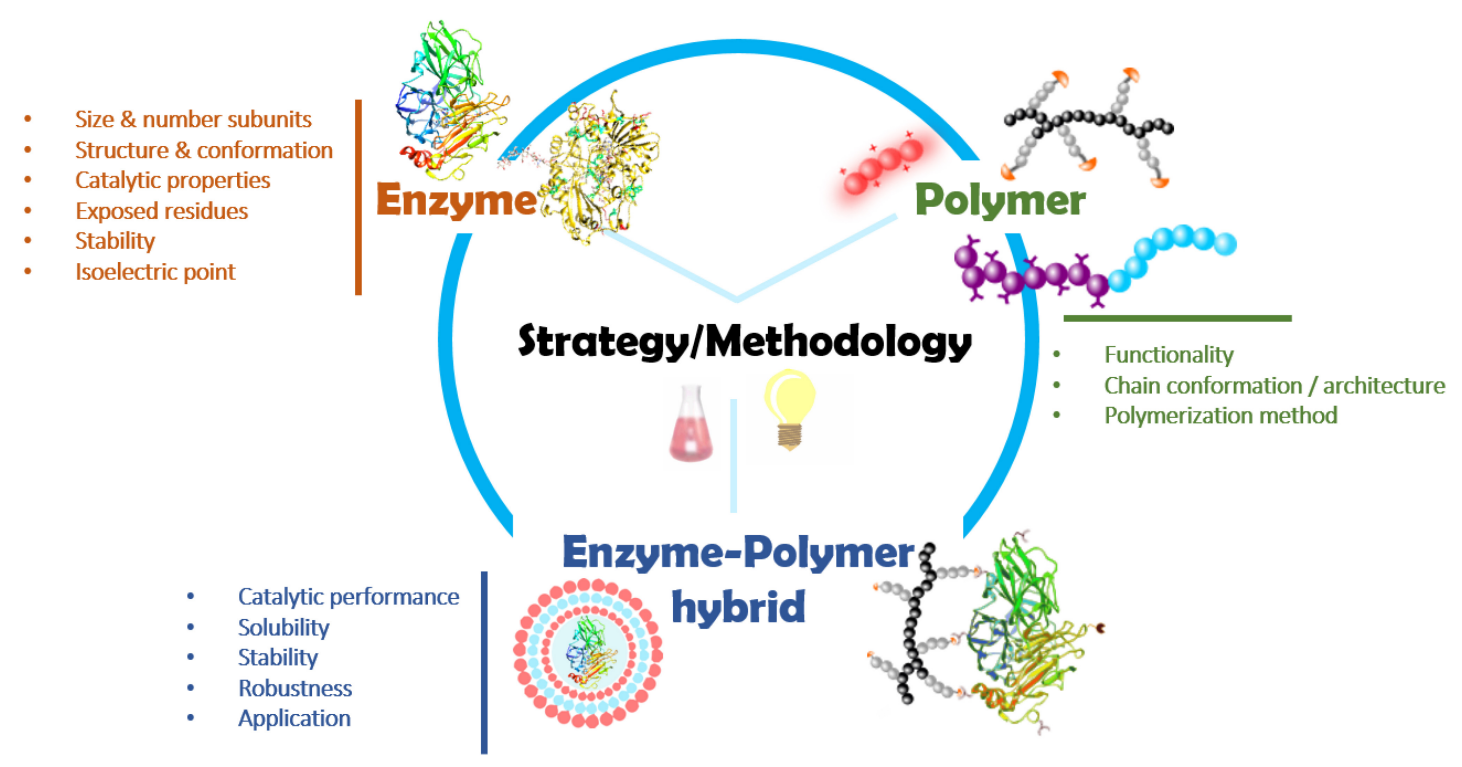

SCHEME 1 | The synthesis of enzyme-polymer hybrids requires the selection of a rationally designed methodology in line with the selected polymeric material and the properties of the enzyme, which should keep the catalytic performance all along the synthesis procedure and in the eventual supramolecular structure. In this process, several parameters (some of which are highlighted in the scheme) need to be considered for a successful fabrication of enzyme-polymer hybrids.

Nillson and Griffin, in a pioneering work in 1916, were able to immobilize the invertase enzyme by physical adsorption to charcoal whilst maintaining its activity (Nelson and Griffin, 1916). Since then, aiming at overcoming the main drawbacks of the utilization of enzymes, i.e., low stability and costly production, many methodologies have been employed to tether enzymes to organic and inorganic materials. So far, poly(ethylene glycol) (PEG) is the most widely used and described polymer utilized to modify proteins. This polymer has been mainly placed to increase the solubility and/or stability of the hybrid system as a consequence of the shielding effects provided by the associated polymer (Cobo et al., 2015). Thus, PEG-protein hybrids show improved solubility, increased stability against degradation, increased circulation times, and prolonged biological activity (Krishna and Kiick, 2010). Fortunately, nowadays, the rapid growth of polymer chemistry offers a wealth of opportunities for the successful combination of enzymes with versatile natural or synthetic polymers. This combination gives rise to a huge diversity of structures and functionalities that embraces a wide range of applications in several research fields such as biocatalysis, biomedicine or biosensing. In the specific case of the field of biocatalysis, the benefits of anchoring synthetic polymers to catalytic proteins are multifold (Zhang Y. et al., 2015). Only through the combination of both (bio)materials, enzymes can reach unique regulated conformational properties such as nanostructured organization and supramolecular assembly. In this regard, the polymeric component can be just a mere solid architecture that provides suitable anchoring sites for the enzyme (widely used in the field of heterogeneous biocatalysis), or can participate actively in tailoring the properties of the enzyme in pursuit of a synergistic enhancement of the catalytic system.
The fabrication of enzyme-polymer hybrids is not a straightforward process, but a carefully designed strategy that should be optimized for each enzyme-polymer pair. Thus, in a well-designed three component system (enzyme, polymer, and methodology) (Scheme 1), not only the enzyme should retain its functionality, but also the polymeric material should provide the catalytic hybrid with the aimed features (e.g., recyclability, stability in organic solvents) to find potential synergistic properties. Hence, the whole procedure should consider several parameters beforehand. Obviously, the selection of the enzyme should be in line with the catalytic reaction that is pursued for the hybrid. In addition to the catalytic profile of the enzyme, other properties of the biomolecule should be also considered such as its size and number of monomers, its structure and conformation, the type and number of residues that are exposed to the environment, and its stability. As example, large proteins might not be suitable for their embedment into the porous network of the polymers. Moreover, it is of high importance to consider the isoelectric point of the enzyme that, besides being strongly related to the conformation and stability of the biomolecule, it can determine the feasibility of the conjugation reaction to the polymers, particularly when lysines are targeted.

Furthermore, the polymeric component also needs several considerations. The selection of the polymer and, in turn, of the methodology, will also rely upon the structure of the hybrid that is sought. Linear and water-soluble polymers are usually interesting for the stabilization of enzymes in solution (e.g., PEGlylated enzymes), whilst insoluble and more complex polymeric networks are used for the fabrication of hybrid heterogeneous biocatalysts (e.g., monoliths due to the high porosity or polymer films for biosensing due to the electrical conductivity features of some polymers) as is discussed below. In 
addition, the selection of the conjugation strategy that is carried out to couple the protein to the polymeric component must comply with the limitations set to retain the integrity of the biomolecules. In this regard, the addition of organic solvents at high concentration to the enzyme-polymer coupling reaction is usually inadvisable for the most of the enzymes. Further, the chain conformation of the polymer needs to be also evaluated, as large and bulky polymers might result in the hindering of the catalytic pocket of the enzyme, hence lowering its catalytic performance. All in all, the design of a successful experiment, in which a catalytically active, robust, and stable enzyme-polymer hybrid is fabricated, needs the careful study of multiple parameters.

On past decades, different enzyme-polymer immobilization methodologies have arisen, such as the adsorption or entrapment on/into solid polymeric particles, metal organic frameworks (MOFs), fibers, hydrogels, or monoliths; the encapsulation in polymersomes or polymeric capsules; and the preparation of cross-linked enzymes (Zdarta et al., 2018). Herein, we provide a short insight on the most used methods to combine both macromolecules, stressing the benefits/disadvantages of each approach. Moreover, this review attempts to cover the different enzyme-polymer designs and structures supported with recent examples from the literature. For the sake of clarity, we have classified by size the enzyme-polymer hybrids into four categories: single enzyme nanostructures; proteinpolymer particles and capsules; micrometric hybrids; and millimeter structures.

\section{STRATEGIES FOR THE FABRICATION OF ENZYME-POLYMER HYBRIDS}

Over the past few years, numerous strategies have been developed for the fabrication of enzyme-polymer hybrids. The synthesis of the hybrid is facilitated either through the formation of covalent bonds or through non-bonding interactions between the enzyme and the polymer. Although it is not the main focus of this review, we provide a short description of the strategies used for the fabrication of the hybrids, those needed to ease the understanding of the formation of the enzyme-polymer hybrids described below. Thus, there are five main synthetic strategies that are herein exposed: covalent bonding, ionic and non-ionic interactions, physical entrapment, encapsulation, and affinitybased interactions. Whilst the first strategy means the formation of a strong bond between the two macromolecules, the driving force for the other four strategies is based on weak interactions such as Van der Waals interaction, hydrogen bonding, and ionic and affinity interactions. Importantly, it is worth mentioning that most of the hybrid structures that are herein detailed can be fabricated through more than one of the following strategies.

\section{Enzyme-Polymer Fabrication Through Covalent Bonding}

The covalent attachment of preformed polymers to a target enzyme is a widely used approach in the synthesis of enzymepolymer conjugates (EPCs). Synthetic polymers can be designed with a large variety of architectures (e.g., linear or branched polymers) and functional end-groups to eventually react with several residues on the enzyme surface in a procedure that is generally known as grafting-to methodology (Figure 1) (Averick et al., 2015).

\section{Non-specific Covalent Binding}

Either single or multiple polymer chains can be tethered to the surface of the protein (Figure 1A). The number of anchored polymers relies on the nature and the number of amino acids that are targeted and on the steric issues that might be intrinsic to some polymer chains (e.g., bulky polymers or dendrimers), as is further discussed below. Alternatively, the use of branched polymers or networks allows the covalent modification of single enzymes from more than one unique point, increasing thereupon the stability of the enzyme (Figure 1B). This multipoint strategy is particularly relevant for the immobilization and stabilization of multi-subunit enzymes. Polymeric supports such as agarose, epoxy resins or polymethacrylate functionalized by glutaraldehyde (GA) or glyoxal groups are extensively used for the multipoint covalent immobilization of enzymes (Guisán, 1988).

Among all the amino acids of the protein, lysines and cysteines are likely the most targeted residues to carry out covalent bonding-based modifications of proteins. The predominance of lysine residues on the surface of the enzyme, usually exposed to the environment and thus accessible to the grafting polymer, facilitates the conjugation event. Different chemistries that lead to the formation of the amide bond can be employed, such as carboxylic acid-amine group reactions via carbodiimide chemistry (Hermanson, 2008) or amine-aldehyde additionelimination reactions (Tao et al., 2004). Yet, the latter could trigger non-site-specific conjugations, modifying thereby other non-targeted residues, i.e., N-terminal amines, histidines, and tyrosines, in a minor degree (Turecek et al., 2016). In addition, the fact that all environmentally accessible lysines can react to some extent, leads to a poor control on the density of polymers and in their orientation on the surface of the proteins. Therefore, this approach generally results in a heterogeneous mixture of enzyme-polymer hybrids, provoking the decrease of the activity and the need of a laborious purification of the resultant mixture of the hybrids with different polymer loads (Canalle et al., 2010). On the other hand, free cysteines have raised as the most convenient target for the site-selective conjugation of native proteins. The highly nucleophilic sulfhydryl side chain group within cysteines can undergo alkylation with maleimides or iodoacetamides. In addition, they can be reacted with disulfidecontaining reagents via exchange procedure (Jung and Kwon, 2016). Unfortunately, it is often challenging to target cysteine residues, as they are among the rarest residues, usually involved in disulfide bonds or buried in hydrophobic pockets. For this reason, other site-selective approaches that target less abundant residues are being developed.

\section{Use of Biorthogonal Chemistry}

For those experiments in which a high degree of control of the hybrid is a must, in terms of both the grafting density and the precise localization of the chains on the surface of the enzyme, 


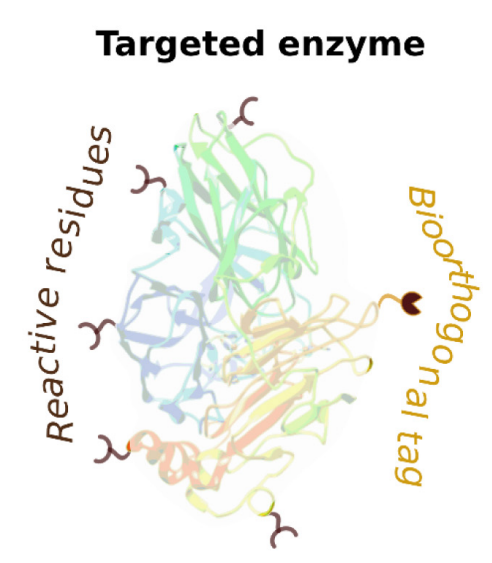

A

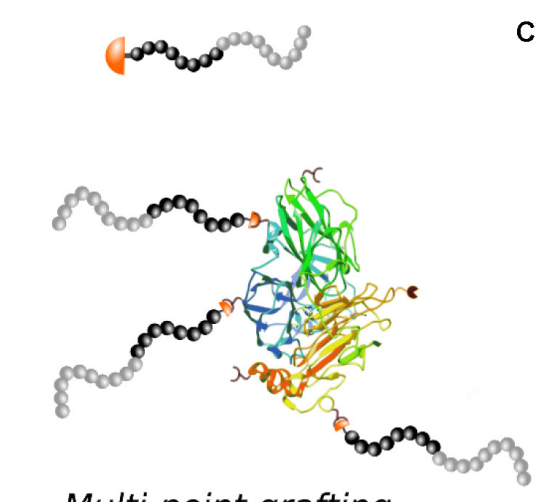

Multi-point grafting

B

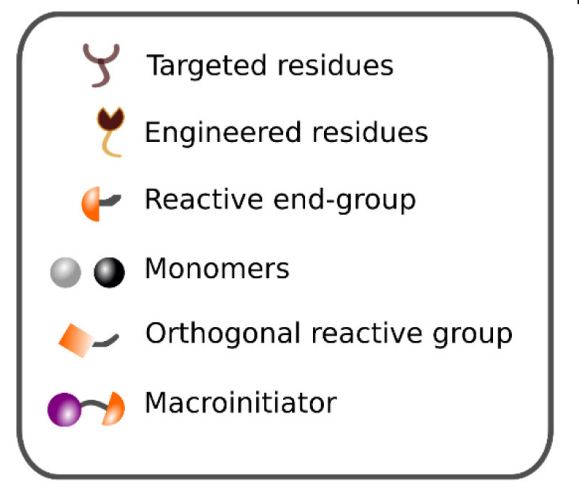

Non-specific grafting
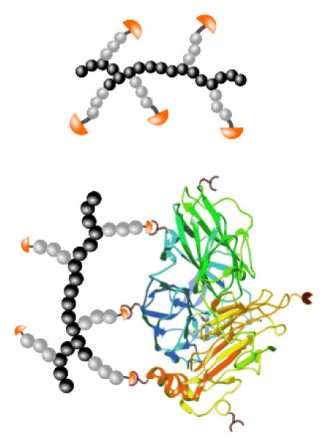

C
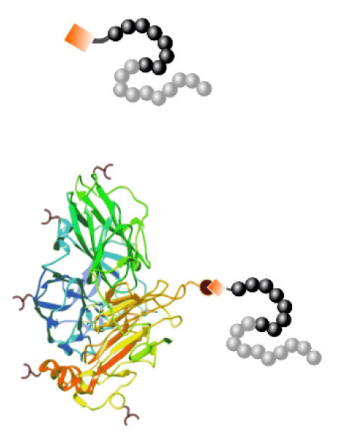

Site-specific grafting

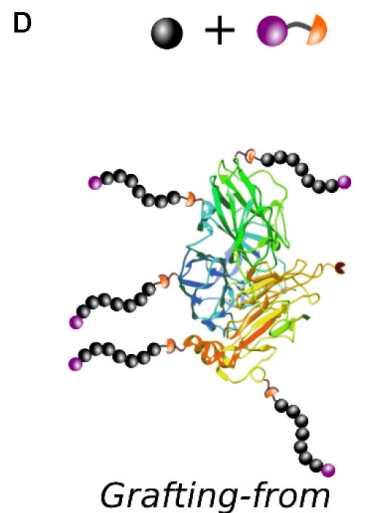

FIGURE 1 | Schematic illustration of polymer-enzyme hybrids synthesized through different covalent-based methodologies. Strategies (A-C) require the synthesis of a preformed polymer (grafting-to approach) and (D) refers to the in situ synthesis of the enzyme-polymer hybrid (grafting-from approach). (A) Non-specific grafting of proteins, using polymers with a single reacting group and proteins with several target residues. (B) Multi-point strategy using polymers with multiple anchoring sites. (C) Site-specific grafting using a biorthogonal approach. (D) Grafting-from approach that entails the conjugation of the macroinitiator to the protein and the subsequent in situ polymerization after the addition of the monomers.

highly efficient bioorthogonal chemistries are applied. Successful stories of site-selective bioconjugation have been achieved using thiol-ene (Jung and Kwon, 2016), alkyne-azide (Boyer et al., 2009), Diels-Alder (Sun et al., 2008) or Staudinger (Serwa et al., 2010) "click" reactions. The bioorthogonal reactions can be performed in presence of many nucleophiles, electrophiles, reductants, oxidants, or water without altering or affecting the evolution of the reaction, because they are not present in biological systems. The two biorthogonal moieties react selectively to each other under mild conditions. The formed covalent bonds are stable, and the byproducts innocuous. This strategy requires the insertion of exogenous functional groups (e.g., azide, hydrazine, alkyne, or allyl sulfide) to the protein. Such chemical handles can be introduced by the insertion of unnatural amino acids in the primary sequence of the protein through genetic engineering or by the direct labeling using other enzymes (e.g., subtiligase, microbial transglutaminase or farnesyltransferase) (Zhang Y. et al., 2018). On the other hand, the polymer component bears the complementary chemical handle in order to carry out a highly specific covalent reaction with the engineered enzyme under mild conditions (Figure 1C).
Many hybrids such as single enzyme-polymer nanoconjugates (Wright et al., 2019), enzyme-MOF conjugates (Gkaniatsou et al., 2017), polymer brushes (Jiang and Xu, 2013), or polymer monoliths (Ma et al., 2019) have been successfully synthetized following this approach.

A large extent of proteins have been covalently bound by grafting to approach, mainly therapeutic proteins, but also enzymes with industrial interest and model proteins for proofof-concept studies. In general terms, the main benefit of grafting to lies in that a broad spectrum of fully characterized preformed polymers can be attached to the enzymes, either site-specifically or randomly. However, there is a considerable issue with the attachment of bulky polymers or dendrimers that have intrinsic steric problems or hindered functional groups in their structure (Wang and Wu, 2018). Furthermore, a high grafting density is usually difficult to achieve using this approach (Carmali et al., 2017).

\section{Grafting-From Approach}

Aiming at increasing the grafting density and at targeting bulky polymers on the surface of the protein, a second approach known 


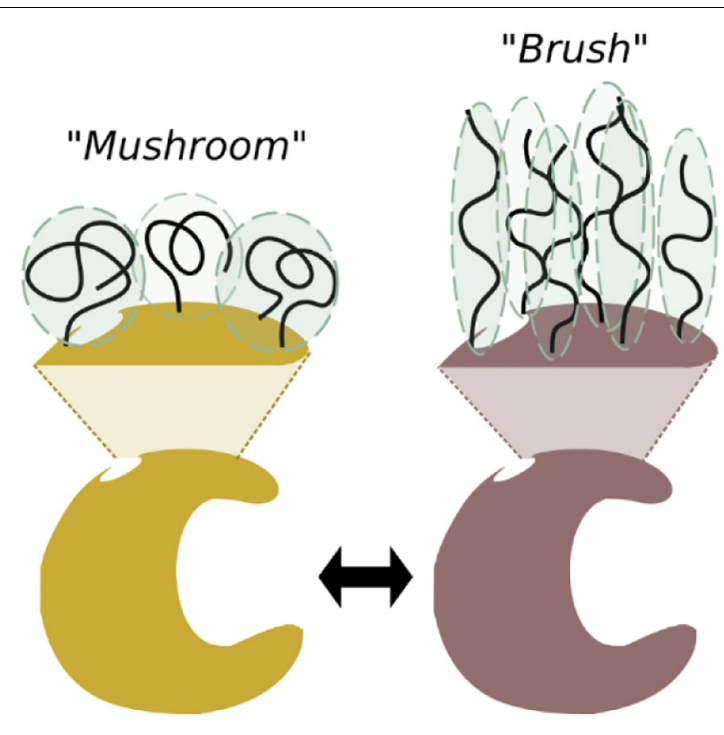

FIGURE 2 | Polymers can be displayed over the enzyme surface in different configurations according to the grafting density. So called "mushroom" or "brush" configurations are achieved at low and high grafting density, respectively.

as grafting from arose (Messina et al., 2020). This approach consists in the in situ growth of the polymer, starting from the reaction initiators or chain transfer agents conjugated to the enzyme beforehand (Figure 1D). The grafting from approach demands mild polymerization conditions in order to, from one side, retain the catalytic properties of the enzymes and, from the other side, allow a precise control of the molecular weight of the polymer and the preservation of the chain-end functionality. In this regard, atom transfer radical polymerization (ATRP) and reversible addition fragmentation chain transfer polymerization (RAFT) are the most utilized techniques that fulfill the aforementioned requirements (Bontempo and Maynard, 2005; Boyer et al., 2007). Compared to grafting to, grafting from approach offers easier downstream purification as the monomers are much smaller than the conjugate itself. Moreover, at high monomer concentration, the entropic penalty of coupling two macromolecules is lowered, and more functional groups can be introduced. Therefore, the synthesis procedure can be tailored in order to tune the grafting density of the polymers on the surface and thus the configuration in which the polymers are presented. While low-density modifications lead to the "mushroom" configuration, the grafting from approach allows the highly dense configuration ("brush" configuration) (Figure 2), which usually leads to enhanced stability and higher solubility of enzymes in non-native environments (Ko and Maynard, 2018).

\section{Enzyme-Polymer Hybrid Fabrication Through Non-covalent Bonding}

Non-covalent enzyme-polymer conjugation strategies present an alternative route for enzyme modification. These approaches involve the adsorption of polymers on the surface of the enzyme through weak interactions, the entrapment of enzymes within a polymeric support, the encapsulation of enzymes into polymeric supramolecular assemblies, and the non-covalent specific bioaffinity binding of both components (Figure 3). As mentioned above, the selection of method, and hence the structure of the hybrid, must be in accordance with the application which the catalytic system will be involved in. Moreover, as discussed below, the physico-chemical properties (i.e., charge surface, polarity, molecular weight, and isoelectric point) and stability of the candidate enzyme is a key factor to be considered before the selection of the method.

\section{Physical Adsorption}

Physical adsorption is the most used non-covalent method due to its simplicity. The main interactions responsible for the adsorption process include Van der Waals forces, hydrogen bonds, and ionic and hydrophobic interactions (Figures 3A,B). These interactions are highly dependent on the environment, i.e., $\mathrm{pH}$ and ionic strength, and therefore can lead to protein leakage issues (Jesionowski et al., 2014). Thus, the effectiveness of the formation of the enzyme-polymer hybrid through adsorption entirely depends on the physico-chemical features of the enzyme and the support, such as charge, hydrophobicity, and the possibility to form hydrogen bonds. In this regard, the adsorption strategies may not offer the control over the spatial orientation of the proteins on the support, which can result in a decrease of the apparent biological activity of the system (Mateo et al., 2007). Notably, this approach is successfully used with lipases, well-known enzymes highly used in distinct industrial sectors. Most types of lipases have a peptide "lid" covering the active site. When the enzyme is adhered to hydrophobic interfaces, the "lid" changes to "open" conformation, enabling the access of the substrate to the active site and enhancing thereby the lipase activity dramatically, up to $50 \%$ of the activity of that shown by the native lipase (Palomo et al., 2002). There are many other examples of enzymes immobilized through adsorption on polymeric materials such as laccase (Labus et al., 2012), glucose oxidase (Koenig et al., 2016), carbonic anhydrase (Assarsson et al., 2014), and cellulase (Wang S. et al., 2013). Furthermore, there are interesting biopolymers for adsorbing enzymes, such as chitosan, calcium alginate, cellulose, agarose, or commercially available ion-exchange resins. Synthetic polymers with hydrophobic interfaces also form a large and diverse group of enzyme carriers. The most commonly used ones include poly(vinyl alcohol) (PVA), poly(Nmethylolacrylamide) (PMAA), polypropylene (PP), polystyrene (PS), poly(hydroxybutyrate) (PHB) or poly(acrylonitrile) (PAN) (Jesionowski et al., 2014).

\section{Physical Entrapment of Enzymes}

The entrapment of enzymes within the cavities of polymeric matrixes, such as MOFs, electrospun fibers or hydrogels, is another noteworthy method for the fabrication of enzymepolymer hybrids (Figure 3C). The enzyme is trapped either during (in situ approach) or after the assembly of the polymers into networks or supramolecular structures. The entrapped enzymes typically show enhanced stability compared to those located on the surface through adsorption (Hiep Nguyen 


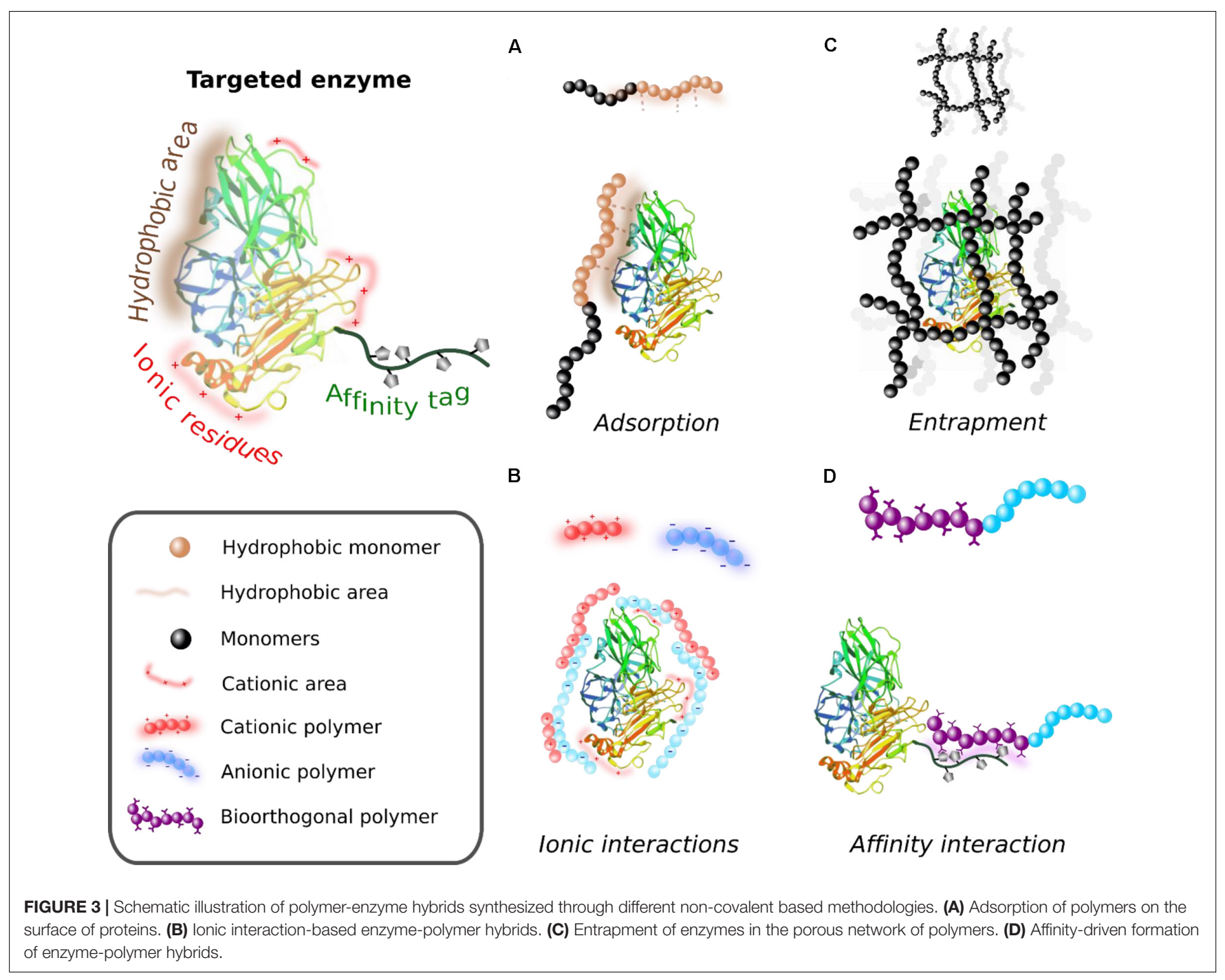

and Kim, 2017). The microenvironment, i.e., pH, polarity or amphiphilicity, and the matrix pore size can be adjusted although inefficient mass transfer is generally observed for the enzymes deeper entrapped (Sassolas et al., 2012). In contrast, large pore sizes of the matrix support are likely to suffer from enzyme leakage. There are several assembled supramolecular polymeric structures utilized for the embedment of enzymes [i.e., polymersomes, reverse micelles, polyion complex vesicles (PICsomes), and layer-by-layer capsules]. The most commonly utilized procedures are based on copolymer self-assembly, layerby-layer (LbL) assembly, and emulsion polymerization synthesis (Cuomo et al., 2019). Additionally, polymerization-induced selfassembly (PISA) synthesis approach for enzyme encapsulation is standing out from the rest of methods because of its simplicity, mild assembly conditions, and broad versatility. Furthermore, the self-assembly of amphiphilic block copolymers in presence of enzymes is carried out in water. In this way, the hydrophobic interactions between the nonpolar blocks of the growing polymers are enhanced, giving rise to the spontaneous assembly into ordered structures such as polymersomes or reverse micelles, leaving the enzymes confined inside (Matoori and Leroux, 2020). Moreover, this assembly strategy can be combined with different techniques of polymerization, i.e., RAFT, ROMP, ATRP, anionic polymerization, and ring opening polymerization (Varlas et al., 2019).

\section{Affinity-Based Approach}

Affinity-based methods are also utilized for the controlled and site-specific modification of enzymes on/in polymeric materials using specific non-covalent interactions (Figure 3D). Several are the benefits of using affinity immobilization methods. The affinity-based interactions are usually reversible, which enables the recycling of the supporting material when the attached enzyme loses activity. Also, despite being a reversible bonding, the interactions between the enzyme and the polymeric material are specific and stable under usual working conditions. Furthermore, natural or artificial epitopes or tags are strategically inserted in the protein in order to promote a favorable orientation, which usually enhances the catalytic performance of the enzyme. Several examples of peptide-tags that are 
artificially introduced in recombinant proteins can be found in the literature [e.g., cellulose-binding domains (CBDs) (Dai et al., 2017), SNAP Tag (Fang et al., 2019), matter-tag (Dedisch et al., 2020), solid-binding peptides (Care et al., 2017), or FLAG tag (Vishwanath et al., 1997)]. The most used polymers bear affinity tags such as nitrilotriacetic acid (NTA) functionalization or avidin/streptavidin motifs, which are used to tether Histagged or biotinylated proteins, respectively. Indeed, enzyme immobilization on polymers mediated by chelated transition metals (Coulet et al., 1981) has been proven as one of the most convenient methodologies for enzyme immobilization and purification (Yakup Arica and Bayramoglu, 2004). Metalligand coordination guided immobilization lowers the mass transfer resistance of the substrate/product. Moreover, the biocatalyst can be easily recovered (Bayramoglu et al., 2010). The variety of affinity-based approaches is huge and is continuously growing [e.g., cellulose binding domains-cellulose and chitin (Kowsari et al., 2014), glycosylated polymers-lectin (LópezGallego et al., 2012), calmodulin protein domain-phenothiazine ligands (Daunert et al., 2007), etc]. For further details, we recommend Barbosa et al. (2015), where the main domains for affinity enzyme immobilization are reviewed.

\section{ENZYME-POLYMER HYBRIDS}

Enzyme-polymer hybrids can be assembled into a plethora of structures, from the simplest enzyme-polymer linear structures to the complex supramolecular polymersomes, ranging from the nanoscale to the macroscopic size. As mentioned before, the selection of the appropriate polymers, guided by the convenient methodology, will address the morphology and the size of the achieved catalytic system. From the catalysis perspective, smallest hybrids, with less non-catalytic material, can achieve much higher enzyme loading capacity and significantly lower diffusion issues. However, larger structures usually stabilize the enzyme in a major degree. In this review, we summarize the most relevant structures found in the literature, sorted out by the size of the enzyme-polymer hybrid, from nanobiocatalysts to microand macrosystems.

\section{Assembly Into Nanobiocatalysts (10-200 nm)}

Recently, joint efforts in the fields of biotechnology, polymer chemistry, and nanotechnology have led to significant progresses in the synthesis and characterization of advanced nanobiocatalysts. Hence, protocols have been stablished for the fabrication of efficient single enzyme nanostructures, such as enzyme-polymer conjugates (EPCs) or single-enzyme nanogels (SENs), repeatedly used in the field of therapeutics and biomedicine (examples collected in Table 1). Nanobiocatalysts can be prepared through the attachment of enzymes via classical methods, i.e., covalent conjugation or entrapment, giving rise to hybrid units that comprise one single enzyme, or in combination with nanometric supports such as polymeric nanoparticles and capsules that can be loaded with several biomacromolecules. The main benefits from nanobiocatalysts lie in the high enzyme loadings that are achieved per weight of non-catalytic material. This fact is usually translated into a high catalytic performance of the system. Yet, recycling issues are inherent to the use of nanometric systems.

\section{Single Enzyme Nanostructures}

\section{Enzyme-polymer conjugates $(E P C)(<40 \mathrm{~nm})$}

In last years, the covalent conjugation of synthetic polymers, either through grafting to or grafting from approach, to enzyme surfaces has become a common and very successful way for the generation of active and stable single enzyme polymer conjugates (Figure 1A). Lots of synthetic polymers [e.g., poly(ethylene glycol) (PEG), poly( $N$-isopropylacrylamide) (PNIPAAM), poly(carboxybetaine methacrylate) (PCBMA), poly(oligo(ethylene glycol) methyl ether methacrylate) (POEGMA), poly(quaternary ammonium methacrylate) (PQA), poly(styrene maleic anhydride) (PSMA), to cite some], and biopolymers (e.g., trehalose-based glycomers or elastin-like polypeptides), have been utilized for equipping many enzymes with novel functionalities and hence with broad applicability (Wright et al., 2019). Gauthier and Klok (2010) reviewed most of the enzyme-protein conjugates present in literature until 2010, concluding that the polymer conjugation often diminishes to some point the initial bioactivity, although the stability is greatly improved. However, since 2010, this field has been remarkably evolved in scope and complexity. We currently know that there are several parameters related to the nature of the polymer, i.e., charge, hydrophobicity, length, and functionality, which have a clear impact over the performance of the catalytic hybrid system and need to be precisely controlled. Indeed, several works evaluating the effect of these parameters on the bioactivity have been published in the last years (Table 1). Thus, Baker et al. (2018) synthetized different chymotrypsin ( $\alpha$-CT)-polymer conjugates varying polymer charge, hydrophobicity, and molecular weight. They conjugated zwitterionic PCBMA, neutral POEGMA, neutral to positive poly(dimethylamino)ethyl methacrylate (PDMAEMA), positive quaternary ammonium ion-containing polymers (PQA), and negative poly(styrene-maleic anhydride) (PSMA) of three different chain lengths each. A grafting from approach was followed, targeting the lysine residues of the $\alpha$-CT enzyme. After a careful study and characterization, they observed that the charge of the polymer had a strong influence in the activity. The conjugation of positively charged polymers (PDMAEMA and PQA) to the enzyme surface increased the catalytic efficiency in acidic environments, which was translated into an increase of the affinity (ca. 25\%) toward the negatively charged substrate. This effect is attributed to long-range electrostatic interactions between the polymer and the histidine located in the active site, which fosters the catalytic efficiency. These results point out the importance of designing a suitable environment for each enzyme using tailored polymers that need to be designed for each particular case (Baker et al., 2019).

The effect of the hydrophobicity of the polymeric chain on the activity and stability of the hybrid has also been studied. The synthesis and characterization of $\alpha$-CTPCBMA (poly(carboxybetaine methacrylate)) enzyme-polymer 
TABLE 1 | Summary of the single enzyme nanostructures tackled in this work (from 5 to $40 \mathrm{~nm}$ ).

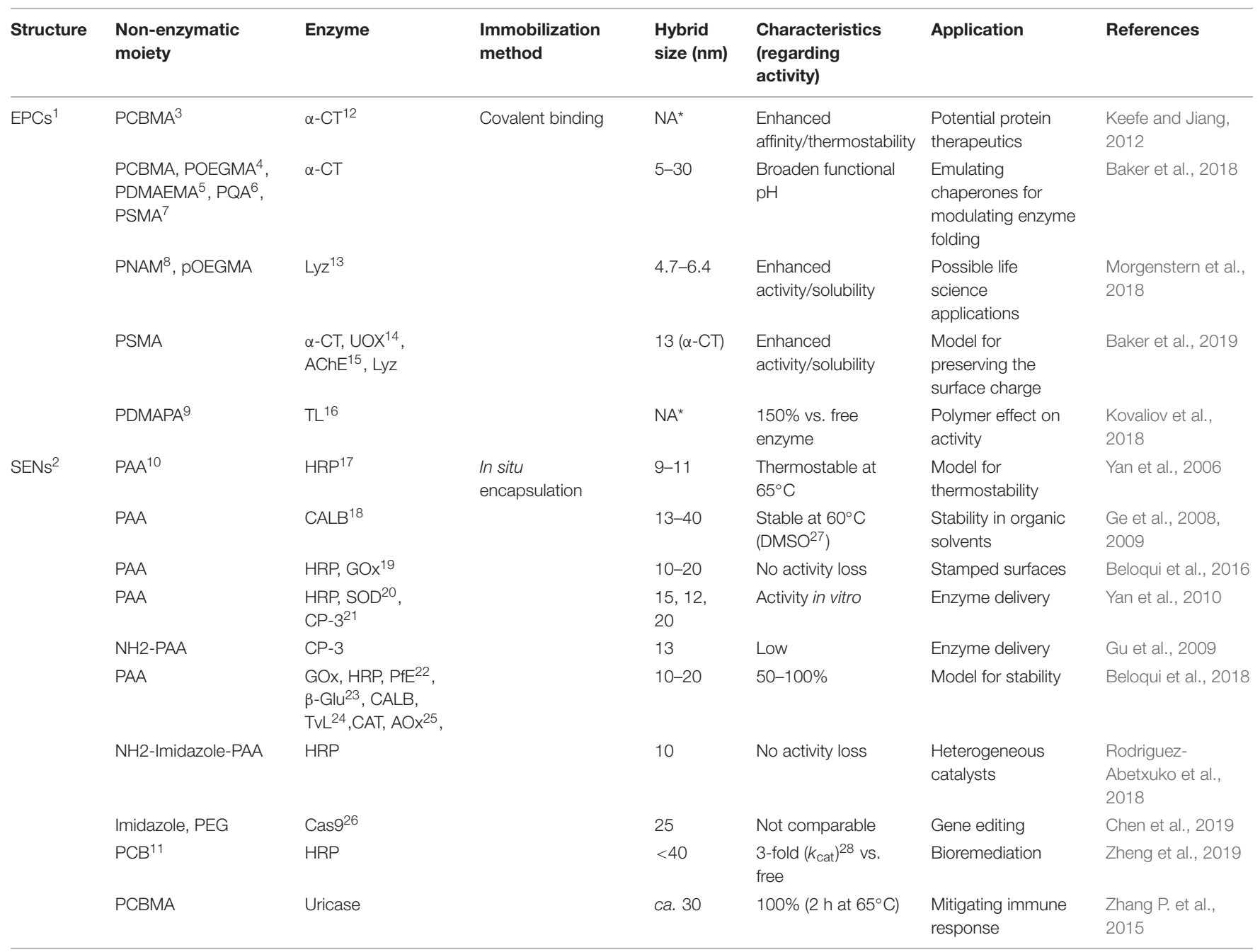

*Not available; ${ }^{1}$ enzyme polymer conjugates; ${ }^{2}$ single enzyme nanogels; ${ }^{3}$ poly(carboxybetaine methacrylate); ${ }^{4}$ poly[oligo(ethylene glycol) methyl ether methacrylate]; ${ }^{5}$ poly(dimethylamino)ethyl methacrylate; ${ }^{6}$ poly(quaternary ammonium methacrylate); ${ }^{7}$ poly(styrene maleic anhydride); ${ }^{8}$ poly(N-acryloylmorpholine); ${ }^{9} \mathrm{~N}$-[3-(dimethylamino)propyl]acrylamide (DMAPA); ${ }^{10}$ polyacrylic acid; ${ }^{11}$ polycarboxybetaine; ${ }^{12} \alpha$-chymotrypsin; ${ }^{13} / y$ sozyme; ${ }^{14}$ urate oxidase; ${ }^{15}$ acetylcholinesterase; ${ }^{16}$ thermomyces lanuginose lipase; ${ }^{17}$ horseradish peroxidase; ${ }^{18} \mathrm{Candida}$ antarctica lipase B; ${ }^{19}$ glucose oxidase: ${ }^{20}$ superoxide dismutase; ${ }^{21} \mathrm{caspase;}{ }^{22} \mathrm{Pseudomonas}$ fluorescens esterase; ${ }^{23} \beta$-glucosidase; ${ }^{24}$ Trametes versicolor laccase; ${ }^{25}$ alcohol oxidase; ${ }^{26} \mathrm{CRISPR}$ associated protein $9 ;{ }^{27}$ dimethyl sulfoxide; ${ }^{28}$ catalytic constant.

conjugates (EPCs) elucidated interesting remarks (Keefe and Jiang, 2012). Apparently, the high hydrophilicity of PCBMA strengthens the hydrophobic interactions that hold the tertiary structure of the protein. Moreover, the affinity of the enzyme toward the peptide-based substrate was increased by a $30 \%$ due to stronger enzyme-substrate hydrophobic-hydrophobic interactions. Moreover, the effect of the PCBMA polymer in the biocatalyst goes beyond the enhancement of the catalytic performance. They also observed that the $\alpha$-CT-PCBMA hybrid was really stable compared to the native enzyme at high temperatures (almost $100 \%$ of the activity conserved at $50^{\circ} \mathrm{C}$ ) and in the presence of denaturing agents.

Furthermore, besides the charge and hydrophobicity of the polymers, the position of the conjugation site, the grafting density, and the molecular weight of the attached polymer are other parameters that have a clear impact on the activity and stability of EPCs. Obviously, the tethering of long and bulky polymers close to the substrate tunnel or catalytic cavity of the enzyme is undesirable in order to avoid the obstruction of the substrate diffusion to the catalytic site. A similar effect occurs with heavily dense grafted hybrids. In this regard, Morgenstern et al. (2018) evaluated the influence of the polymer molar mass and protein conjugation degree on the solubility, aggregation behavior, and in vitro activity of poly( $N$-acryloylmorpholine) (PNAM)- and POEGMA-based lysozyme conjugates synthetized by grafting-to approach. The conjugates with larger polymer chains, as well as the polyvalent conjugates, showed a reduced catalytic activity, attributed to the shielding of the catalytic site by the polymer. However, the monovalent conjugates with the shortest polymeric chains showed moderately increased activities compared to native lysozyme (Morgenstern et al., 2018). However, it has been demonstrated that a well-controlled grafting density and polymer length, i.e., using grafting-from approach, can trigger the 
enhancement of the catalytic activity. Thus, the controlled grafting of positively charged polymers close to the active center can increase the effective concentration of the negatively charged substrates and thereby boost the activity of the biocatalyst (Kovaliov et al., 2018). These examples showcases that the synthesis of successful EPCs requires a careful design of the parameters of the polymer but also a suitable synthesis strategy that allows the achievement of new opportunities to the biocatalyst.

\section{Single enzyme nanogels (SENs) $(<40 \mathrm{~nm}$ )}

Single enzyme nanogels have arisen as a promising technology in which enzymes are trapped individually by a thin hydrogel layer. The synthesis is performed in situ, giving rise to core-shelllike structures, in which the biomolecules remain in the core and the polymer works as a protective shell. These structures generally show catalytic performances close to that exhibited by the native enzyme. Also, a clear enhancement of the stability at high temperatures and in presence of organic solvents is observed. The synthesis consists of a two-step procedure. First, vinyl groups are anchored to the protein through the covalent modification of lysine residues. Thereafter, the in situ free radical polymerization is performed on the surface of the protein by the co-addition of monomers, crosslinkers, and the acryloylated enzyme at room temperature (Yan et al., 2006). The mechanism that undergoes nanocapsule formation was elucidated by molecular simulation. It was demonstrated that the monomers are locally concentrated around the enzyme surface prior to polymerization, via hydrogen bonding, additional static electronic forces, and hydrophobic interactions (Ge et al., 2008). The thermostability of several enzymes was significantly enhanced using this strategy. As example, horseradish peroxidase (HRP) nanogels could conserve the $80 \%$ of its initial activity after 90 min of incubation at $65^{\circ} \mathrm{C}$, while native HRP was totally inactivated under the same conditions. Moreover, in presence of organic solvents, the activity of HPR was also retained due to the hydrophilic environment formed by the nanogel. The authors attributed the enhanced thermal stability of the HRP nanogel to the multiple interactions between the polymeric network and the protein (Ge et al., 2009; Beloqui et al., 2016).

The synthesis procedure of SENs has been optimized in order to broaden the applicability of the technology to a wide range of enzymes and monomers (Figure 4A). It has been demonstrated that the addition of small amounts of sucrose triggers the reduction of hydrophobic/hydrophilic repulsion forces between monomers and enzymes, increasing thereby the concentration of the monomers on the surface of the protein and thus enhancing the encapsulation yield to almost $80 \%$ (Beloqui et al., 2018). It has been also observed that it is possible to control the thickness of the capsule, regardless the sort of protein utilized, only varying the monomer concentration. Importantly, it was found that layers with more than $2 \mathrm{~nm}$ thickness are detrimental for the enzymatic activity. Thicker layers lead to mass transfer issues. In more recent examples, new functionalities have been introduced into the polymeric shell, i.e., hydroxyl, amino, carboxyl, and imidazole groups (Figure 4B), which have been further utilized as building blocks for the synthesis of heterogeneous catalysts for biocatalysis or biosensing (Rodriguez-Abetxuko et al., 2018, 2019a,b). Indeed, SENs, which were initially conceived to enhance the stability of the enzyme, have been also applied in different fields. Zwitterionic capsules, which confer extreme hydrophilicity, antifouling properties, and non-immunogenicity, have been utilized for therapeutics and the removal of pollutants (Zhang P. et al., 2015; Zheng et al., 2019). Moreover, the small size of SENs makes them an interesting vehicle for protein delivery in vivo (Gu et al., 2009; Yan et al., 2010; Biswas et al., 2011). In this regard, Cas9 ribonucleoprotein complex was successfully encapsulated and delivered for gene-editing experiments using degradable nanocapsules (Chen et al., 2019). Certainly, the advances achieved in the lasts years derive into the encapsulation of enzymes into complex and smart polymers that might enable the inclusion of this technology into other hot fields, such as the chemoenzymatic catalysis or biohybrid light emitting diodes (Rodriguez-Abetxuko et al., 2020).

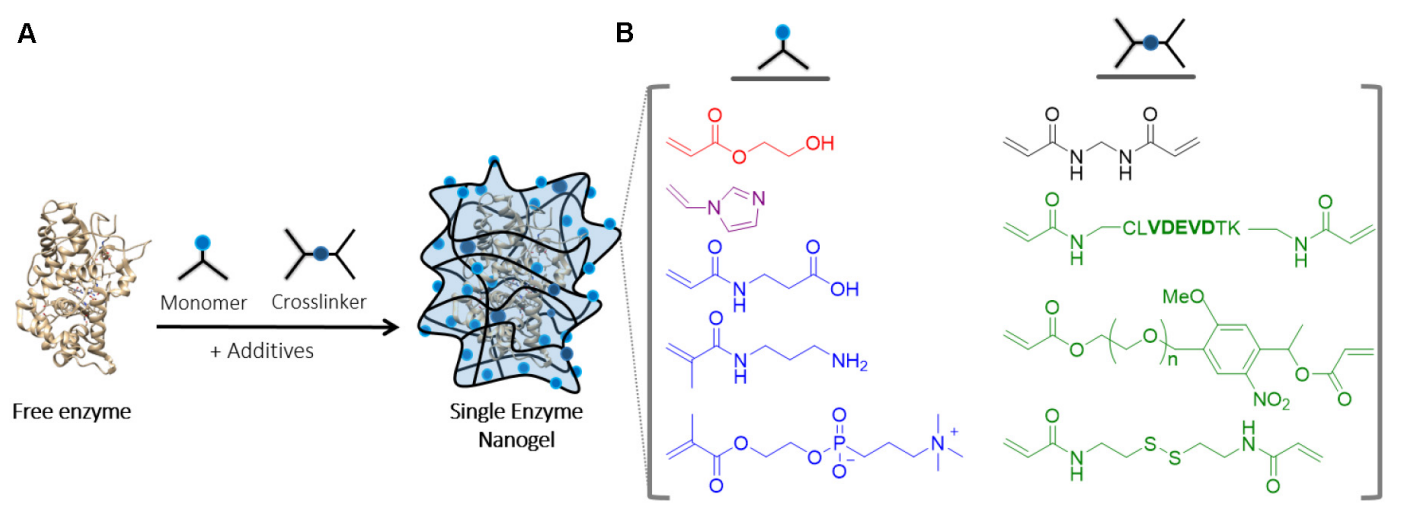

FIGURE 4 | Synthesis of single enzyme nanogels. (A) Fabrication procedure of single enzyme nanogels by in situ radical polymerization. (B) We showcase some of the most used monomers and crosslinkers. Selected monomers can provide hydrophilicity (red), the ability to complex metal cations (purple) or tune the ionic interactions within the polymeric shell (blue). Moreover, the use of labile crosslinkers allows the release of the protein under external stimuli (presence of a peptidase, light or redox reagents for the examples drawn in green). 
TABLE 2 | Summary of enzyme-polymer nanohybrids in which the enzyme is displayed to the environment.

\begin{tabular}{|c|c|c|c|c|c|c|c|}
\hline Structure & $\begin{array}{l}\text { Non-enzymatic } \\
\text { moiety }\end{array}$ & Enzyme & $\begin{array}{l}\text { Immobilization } \\
\text { method }\end{array}$ & $\begin{array}{l}\text { Hybrid size } \\
\quad(\mathrm{nm})\end{array}$ & $\begin{array}{l}\text { Characteristics } \\
\text { (regarding } \\
\text { activity) }\end{array}$ & Application & References \\
\hline \multirow[t]{2}{*}{ Micelle corona } & Pluronic F127 & $\mathrm{OPH}^{8}$ & $\begin{array}{l}\text { Covalent } \\
\text { (NHS } 24 \text {-Lys) }\end{array}$ & 120 & $\begin{array}{l}1.5 \text {-fold increase } \\
\text { vs. free enzyme } \\
\left(k_{\text {cat }}{ }^{28}\right)\end{array}$ & Bioremediation & $\begin{array}{l}\text { Suthiwangcharoen } \\
\text { and Nagarajan, } \\
2014\end{array}$ \\
\hline & POEGMA ${ }^{2}$ & HRP $^{9}$, Est $^{10}$ & Affinity $\mathrm{Ni}^{2+} / \mathrm{His}$ tag & $130-220$ & $\begin{array}{l}\text { 3-fold decrease vs. } \\
\text { free HRP }\left(k_{\text {cat }}\right)\end{array}$ & $\begin{array}{l}\text { Proof of concept } \\
\text { study }\end{array}$ & Keller et al., 2017 \\
\hline & $\begin{array}{l}\text { PAMAM + } \\
\text { dipicolylamine } \\
\text { /zinc (II) }\end{array}$ & $\begin{array}{l}\beta \text {-Gal, RNase } \\
\text { A, SOD } \\
\alpha-C^{16}, \\
\text { HRP, trypsin }\end{array}$ & $\begin{array}{l}\text { lonic and } \\
\text { coordination } \\
\text { interactions } \\
\text { (DPA } \mathrm{DP}^{25} / \mathrm{Zn}^{2+} \text { and } \\
\text { imidazole/amino) }\end{array}$ & 100-200 & Nearly 90\% (HRP) & $\begin{array}{l}\text { Cytosolic enzyme } \\
\text { delivery }\end{array}$ & Ren et al., 2020 \\
\hline \multirow{2}{*}{ NP } & Iron oxide, $\mathrm{PGMA}^{6}$ & $\mathrm{ADH}^{20}, \mathrm{TL}^{21}$ & Covalent $\left(\mathrm{GA}^{26}\right)$ & ca. $70-160$ & $\begin{array}{l}97 \% \text { yield in } \\
60 \text { min }>99 \% \text { ee } \\
\text { (R). } 14 \text { times } \\
\text { recycled } 80 \% \\
\text { activity. } \\
\text { Thermostable at } \\
70^{\circ} \mathrm{C} \text { for } 12 \mathrm{~h} \text {. }\end{array}$ & $\begin{array}{l}\text { Model for } \\
\text { heterogeneous } \\
\text { catalysis }\end{array}$ & Ngo et al., 2012 \\
\hline & Iron oxide, PGMA & OASS $^{22}$ & Affinity (Ni-NTA ${ }^{27}$ ) & 85 & $\begin{array}{l}55 \% \text { activity in the } \\
10 \text { th cycle. }\end{array}$ & $\begin{array}{l}\text { Unnatural aa } \\
\text { synthesis }\end{array}$ & Vahidi et al., 2016 \\
\hline $\begin{array}{l}\text { Self-assembled } \\
\text { EPC }^{1}\end{array}$ & $\mathrm{PHPMA}^{7}$ core & $\mathrm{GO} \mathrm{x}^{23} / \mathrm{HRP}$ & $\begin{array}{l}\text { Covalent, } \\
\text { adsorption }\end{array}$ & $60-68$ & $\begin{array}{l}\text { Fivefold enhanced } \\
\text { cascade activity }\end{array}$ & Glucose detection & Chiang et al., 2020 \\
\hline
\end{tabular}

${ }^{1}$ Enzyme polymer conjugate; ${ }^{2}$ poly(oligo(ethylene glycol) methyl ether methacrylate); ${ }^{3}$ phenylboronic acid; ${ }^{4}$ poly(amidoamine); ${ }^{5}$ polydopamine; ${ }^{6}$ poly(glycidyl methacrylate); ${ }^{7}$ poly(N-(2-hydroxypropyl) methacrylate)); ${ }^{8}$ organophosphate hydrolase; ${ }^{9}$ horseradish peroxidase; ${ }^{10}$ esterase; ${ }^{11} \mathrm{CRISPR}$ associated protein 9 ; ${ }^{12}$ single guide RNA; ${ }^{13} \beta$-galactosidase; ${ }^{14}$ lysozyme; ${ }^{15}$ cytochrome c; ${ }^{16}$ superoxide dismutase; ${ }^{17} \alpha$-chymotrypsin; ${ }^{18}$ Candida antarctica lipase B; ${ }^{19}$ Candida antarctica lipase $A ;{ }^{20}$ alcohol dehydrogenase; ${ }^{21}$ thermomyces lanuginose lipase; ${ }^{22} \mathrm{O}$-acetylserine sulfhydrylase; ${ }^{23}$ glucose oxidase; ${ }^{24} \mathrm{~N}$-hydroxysuccinimide; ${ }^{25}$ dipicolylamine; ${ }^{26}$ glutaraldehyde; ${ }^{27}$ nitrilotriacetic acid; ${ }^{28}$ Catalytic rate constant; ${ }^{29}$ enantiomeric excess.

\section{Enzyme Immobilization Onto/Into Polymeric Nanomaterials}

In the last decades, polymeric nanomaterials with distinct morphologies and properties have been widely used as carrier platforms to confine several enzymes in small volumes. Enzymes can be either tethered to the surface of the polymers, encapsulated into hollow structures, or embedded into the network of porous polymers. This strategy results interesting for multitude of biotechnological applications such as biocatalysis, bioseparations, imaging, biosensing, in vitro biotransformation, drug delivery or therapy (Hola et al., 2015; Bosio et al., 2016) (examples collected in Tables 2, 3). In this section, we have revised the methodologies and structures used for the confinement of enzymes in different nanomaterials up to date. We have classified the hybrids attending to the relative arrangement of the enzyme and the polymeric material: enzymes bound to the surface of the polymer through (non)covalent interactions; enzymes encapsulated in the core of polymeric supramolecular structures; and enzymes entrapped into a specific type of nanoscale polymeric networks, namely, nanoMOFs.

\section{Immobilization on the surface of the nanomaterial}

Polymeric nanostructures, i.e., micelles, dendrimers, and metal/polymer nanoparticles, have a large specific surface area, which makes them ideal to accommodate a dense layer of enzymes that will remain exposed to the environment (Figure 5). While this is an easy and convenient approach to concentrate the biocatalysts in small volumes, the protection provided by the polymer component is in this case very limited compared to the hybrids described in the next sections. In this review, due to their high significance and number of examples in the literature, we want to highlight the hybrids fabricated using four sorts of polymeric nanoarchitectures, namely, polymeric micelles, dendrimers, polymeric nanoparticles, and so called giant amphiphile hybrids.

\section{Polymeric micelles}

Polymeric micelles (ca. 100-200 nm) are nanoscopic coreshell structures formed by amphiphilic block co-polymers in which the hydrophobic part is located in the inner core and hydrophilic part outward. Hence, enzymes can be conjugated 
TABLE 3 | Examples of enzyme-polymer supramolecular nanohybrids in which the enzyme is confined in the inner cavity.

\begin{tabular}{|c|c|c|c|c|c|c|c|}
\hline Structure & $\begin{array}{l}\text { Non-enzymatic } \\
\text { moiety }\end{array}$ & Enzyme & $\begin{array}{l}\text { Immobilization } \\
\text { method }\end{array}$ & $\begin{array}{l}\text { Hybrid size } \\
\text { (nm) }\end{array}$ & $\begin{array}{l}\text { Characteristics } \\
\text { (regarding activity) }\end{array}$ & Application & References \\
\hline \multirow[t]{3}{*}{$\begin{array}{l}\text { Reverse } \\
\text { micelle }\end{array}$} & $\mathrm{BHDC}^{3}$ & $\alpha-\mathrm{CT}^{20}$ & Encapsulation & 11 & $\begin{array}{l}\text { Enhanced efficiency in } \\
\text { water/BHDC }{ }^{37} / \text { benzene }\end{array}$ & Biotransformation & Moyano et al., 2010 \\
\hline & $\mathrm{CTAB}^{4} / \mathrm{AuNP}$ & Lipase & Encapsulation & ca. 40 & $\begin{array}{l}\text { 3.5-fold increase vs. no } \\
\text { NP RMs }\end{array}$ & $\begin{array}{l}\text { Model for } \\
\text { nanoreactor }\end{array}$ & Maiti et al., 2011 \\
\hline & PS-based ${ }^{5}$ & $\mathrm{plE}^{21}, \mathrm{bCA}^{22}, \mathrm{Lyz}^{23}$ & $\begin{array}{l}\text { Encapsulation/Affinity } \\
\text { binding/adsorption }\end{array}$ & $37-50$ & $\begin{array}{l}\text { Activity maintained in } \\
\text { the transport }\end{array}$ & Selective transport & Gao et al., 2018 \\
\hline & PS- $b-P A A^{8}$ & Trypsin & Encapsulated & $30-250$ & $\begin{array}{l}2 \text { orders of magnitude } \\
\text { increase in enzyme } \\
\text { efficiency vs. bulk }\end{array}$ & $\begin{array}{l}\text { Model for } \\
\text { confinement }\end{array}$ & Chen et al., 2009 \\
\hline & 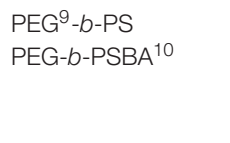 & CALB $^{27}$ & Encapsulated & 200-400 & $\begin{array}{l}\text { Increased with } \\
\text { permeability }\end{array}$ & $\begin{array}{l}\text { Model for } \\
\text { nanoreactors } \\
\text { controlled } \\
\text { permeability }\end{array}$ & Kim et al., 2009 \\
\hline & $\begin{array}{l}\text { PEG-P(Asp), } \\
\text { Homo-P(Asp-AP) }{ }^{13}\end{array}$ & $\beta-\left.G a\right|^{29}$ & Encapsulation & ca. 100 & $\begin{array}{l}\text { 2-fold } K_{m}{ }^{\text {app39 }} \text { vs. free } \\
\text { enzyme }\end{array}$ & Enzyme delivery & Anraku et al., 2016 \\
\hline \multirow[t]{4}{*}{$\mathrm{MOFs}^{2} \mathrm{NPs}$} & $\mathrm{ZIF-8}{ }^{14}$ & $\mathrm{CAT}^{30} / \mathrm{GO} \mathrm{x}^{31}$ & $\begin{array}{l}\text { Covalent bond on } \\
\text { ZIF surface by } \\
\mathrm{GA}^{36}\end{array}$ & ca. 200 & Activity preservation & $\begin{array}{l}\text { Photodynamic } \\
\text { therapy }\end{array}$ & You et al., 2019 \\
\hline & $\begin{array}{l}\text { CC-ZIF }{ }^{15} \text { coated } \\
\text { with cancer cells } \\
\text { membrane }\end{array}$ & Cas932 & $\begin{array}{l}\text { In situ } \\
\text { encapsulation }\end{array}$ & 120 & $\begin{array}{l}\text { Activity preservation, } \\
\text { fast release of Cas } 9\end{array}$ & $\begin{array}{l}\text { CRISPR }^{40} / \text { Cas } 9 \\
\text { delivery }\end{array}$ & Alyami et al., 2020 \\
\hline & $\mathrm{ZIF-8}$ & $\begin{array}{l}\varphi 29 \text { DNA } \\
\text { polymerase }\end{array}$ & $\begin{array}{l}\text { In situ } \\
\text { encapsulation }\end{array}$ & ca. 90 & $\begin{array}{l}\text { Enzyme shielding, } \\
\text { activity preserved }\end{array}$ & $\begin{array}{l}\text { Rolling circle } \\
\text { amplification (RCA) } \\
\text { in vivo }\end{array}$ & Zhang et al., 2019a \\
\hline & $\begin{array}{l}\text { ZIF-8 coating of } \\
\text { PVP }^{17}\end{array}$ & $\beta$-Gal, CP-3 35 & Encapsulation & $70-200$ & Activity preserved & $\begin{array}{l}\text { Biomedical } \\
\text { application }\end{array}$ & Chen et al., 2018 \\
\hline $\begin{array}{l}\text { COF/MOF } \\
\text { NPs }\end{array}$ & $\begin{array}{l}\text { COF42- } \\
\text { B(BBTH/TB }{ }^{18} \\
\text { ZPF-2 }^{19} \text { or ZIF-90 }\end{array}$ & GOx and CAT/GOx & $\begin{array}{l}\text { In situ } \\
\text { encapsulation }\end{array}$ & ca. 1.5 & Increase activity & $\begin{array}{l}\text { Model for cascade } \\
\text { reaction }\end{array}$ & Li et al., 2020 \\
\hline
\end{tabular}

*Not available; ${ }^{1}$ polyion complex vesicles; ${ }^{2}$ metal organic frameworks; ${ }^{3}$ benzyl-N-hexadecyldimethylammonium chloride; ${ }^{4}$ cetyltrimethyl-ammoniumbromide; ${ }^{5}$ polystyrene; ${ }^{6}$ poly(2-methyl-2-oxazoline); ${ }^{7}$ polydimethylsiloxane; ${ }^{8}$ polyacrylic acid; ${ }^{9}$ polyethylene glycol; ${ }^{10}$ poly(ethylene glycol)-b-poly(styrene boronic acid); ${ }^{11}$ PEGpoly $\left(\alpha, \beta\right.$-aspartic acid); ${ }^{12}$ poly([5- aminopentyl]- $\alpha, \beta$-asoartamide); ${ }^{13}$ homo-([5-aminopentyl]- $\alpha, \beta$-aspartamide); ${ }^{14}$ zeolitic imidazolate frameworks; ${ }^{15} \mathrm{CRISPR/Cas9-ZIF;}$ ${ }^{16}$ Universitetet i Oslo-66; ${ }^{17}$ polyvinylpyrrolidone; ${ }^{18}$ covalent organic frameworks-42-B (2, 5- Bis(butenyloxy)terephthalohydrazide/1,3,5-triformylbenzene); ${ }^{19}$ zeolitic pyrimidine framework; ${ }^{20} \alpha$-Chymotrypsin; ${ }^{21}$ porcine liver esterase; ${ }^{22}$ bovine carbon anhydrase; ${ }^{23} / y$ sozyme; ${ }^{24} \mathrm{~N}$-acyl-D-g/ucosamine 2 -epimerase; ${ }^{25} \mathrm{~N}$-acetylneuraminate lyase; ${ }^{26} \mathrm{CMP}$-sialic acid synthetase; ${ }^{27}$ Candida antarctica lipase $\mathrm{B} ;{ }^{28} \mathrm{~L}$-asparaginase; ${ }^{29} \beta$-galactosidase; ${ }^{30}$ catalase; ${ }^{31}$ glucose oxidase; ${ }^{32} \mathrm{CRISPR}$ associated protein 9 ; ${ }^{33}$ cytochrome c; ${ }^{34}$ horseradish peroxidase; ${ }^{35}$ caspase $3 ;{ }^{36}$ glutaraldehyde; ${ }^{37}$ benzyl-n- hexadecyldimethylammonium chloride; ${ }^{38}$ reverse micelles; ${ }^{39}$ apparent Michaelis constant; ${ }^{40}$ clustered regularly interspaced short palindromic repeats.

to the outer hydrophilic part of preformed micelles, modifying the micelle corona (Figure 5A). The micelles usually generate an appropriate environment for the enzymes, enhancing their physicochemical and biological properties. As example, Keller et al. (2017) successfully synthesized micelles of ca. $100 \mathrm{~nm}$ of a hydrophilic [poly(oligoethylene glycol)] methyl ether methacrylate, POEGMA, allocated in the shell of the micelle - hydrophobic [poly(t-butyl acrylate)], PtBA, in the core of the micelle) copolymer following polymerization-induced selfassembly (PISA) approach. The end group of the POEGMA moiety was modified with a NTA (nitrile acetic acid) group in order to target His-tagged enzymes. With this strategy, they achieved a recyclable and robust biocatalysts based on horseradish peroxidase and esterase enzymes (Keller et al., 2017). 


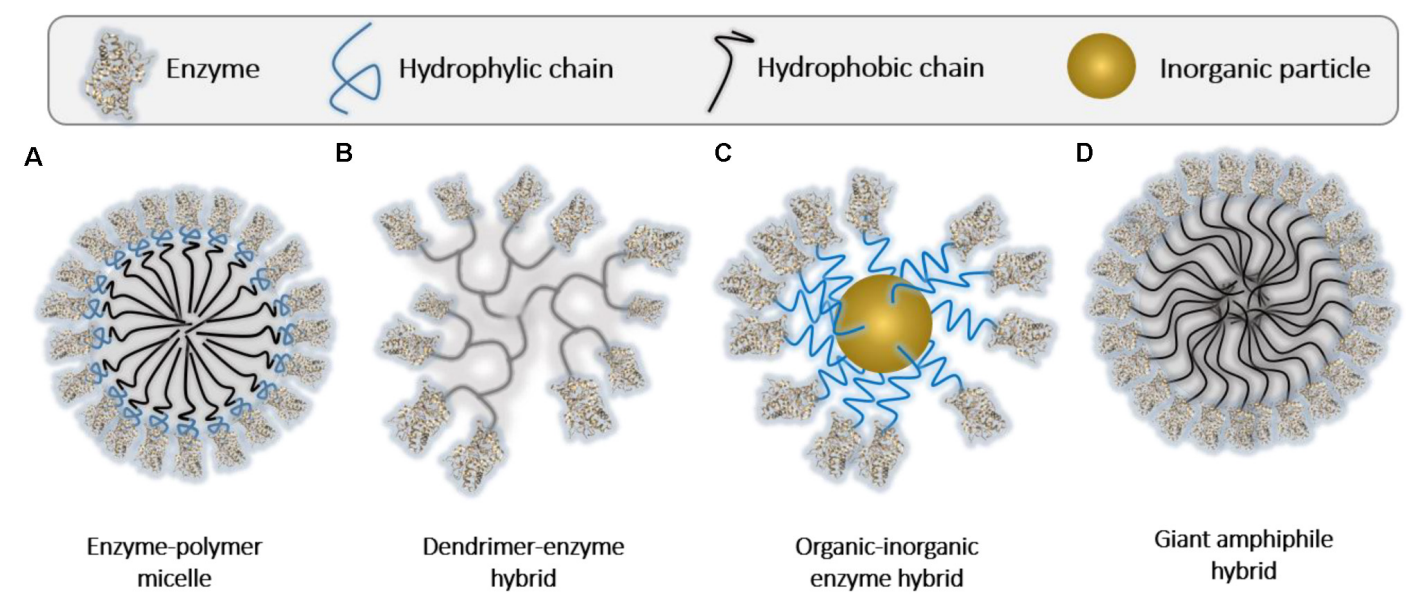

FIGURE 5 | Assembled enzyme-polymer supramolecular hybrids in which the enzyme is displayed to the environment. (A) Enzyme-polymer micelles. (B) Dendrimer-enzyme hybrids. (C) Organic-inorganic enzyme hybrids. (D) Giant amphiphile structures.

Further, the composition of the polymer that prompt the assembly into micelles might have a positive effect on the activity and the stability of the biocatalyst. Indeed, it has been described that Pluronic F127-based micelles enhance the activity of organophosphate hydrolase $(\mathrm{OPH})$ enzyme and its stability compared to the native version under broad conditions (room and high temperature, after multiple freeze/thaw treatments, lyophilization, and in the presence of organic solvents). This interesting effect can be attributed to a possible interaction of the hydrophobic polypropylene oxide block of the Pluronic F127 and the hydrophobic surface domains on the enzyme that are close to ligand pockets (Suthiwangcharoen and Nagarajan, 2014).

\section{Dendrimers}

Dendrimers (ca. 100-200 $\mathrm{nm}$ ) are another interesting tool for enzyme immobilization. A dendrimer is a polymeric molecule composed of multiple branched monomers that emanate radially from a central hydrophobic core, giving rise to micelle-like behavior (Gupta et al., 2006) (Figure 5B). The multiple branches and the high density of functional end-groups of the dendrimers enable the high effectiveness of immobilization through covalent bonding. For example, polyester or poly(amidoamine) (PAMAM) dendrimers can be used as a convenient platform for glucose oxidase or lipase enzymes (Fan et al., 2017; Morshed et al., 2019). Dendrimerenzyme hybrids, mostly PAMAM-based dendrimer particles, are also employed for delivery purposes in biomedicine. In the work of Liu C. et al. (2019), the enzyme immobilization is carried out through the phenylboronic acid (PBA) complex (i.e., cationic amine and imidazole groups on proteins via nitrogen-boronate complexation). This configuration leads to unprecedented efficiency for cytosolic delivery of proteins with different isoelectric points and sizes such as Cas9/sgRNA, trypsin, $\beta$ galactosidase, lysozyme, cytochrome $\mathrm{C}$, horseradish peroxidase, and RNase A (Liu C. et al., 2019). Other examples in which PAMAM dendrimer scaffold is modified with dipicolylamine (DPA)/zinc (II) complex have demonstrated great efficiency in the delivery of enzymes, superior to that showed by commercial TransEx and PULSin delivery systems (Ren et al., 2020).

\section{Nanoparticles}

Inorganic nanomaterials, i.e., nanoparticles (50-200 nm), are usually combined with an interfacial capping layer composed of organic molecules, often polymers, in order to provide stability to the nanomaterial and, at the same time, to facilitate the localization of the enzyme on the surface (Figure 5C). Polymers such as acrylamide, cellulose, and chitosan are mostly used to tether enzymes through both non-covalent and covalent conjugation methods (Bilal and Iqbal, 2019a). With this strategy, the direct enzyme-nanoparticle interaction, which usually leads to a partial denaturation of the protein, is avoided. The presence of polymer, either as coatings or linkers, instead impart a favorable environment to the enzymes (Rodrigues et al., 2013). The main application of these biohybrids are focused on catalysis or biotransformations, as inorganic nanoparticles commonly help enhancing the catalytic activity and recyclability (Breger et al., 2015). Polymer coated magnetic nanoparticles, mostly composed of magnetite and maghemite, are known to be good platforms for catalysts. They show low toxicity, high enzyme loading capacity, and ease the recycling of the biocatalyst. As example, Ngo et al. (2012) fabricated a magnetic nanobiocatalyst by the conjugation of alcohol dehydrogenase (ADH) enzyme to poly(glycidyl methacrylate) magnetic nanoparticles (PGMAMNPs) using glutaraldehyde (GA) as chemical crosslinker. The confined enzymes showed the same activity as the native $\mathrm{ADH}$, with a reaction yield of the 97 and 99\% of enantiomeric excess (ee, R) in $60 \mathrm{~min}$. The system was easy to recycle, keeping the activity around $80 \%$ after 14 cycles of $20 \mathrm{~min}$ each (Ngo et al., 2012). Other enzymes, such as $O$-acetylserine sulfhydrylase (OASS), have been immobilized on PGMA-MNPs through $\mathrm{Ni}^{2+} /$ His-tag affinity binding (Vahidi et al., 2016). Further, non-magnetic nanoparticles (e.g., metallic or silica) are also used (Zhang C. et al., 2018) as core material. There are recent and interesting examples of enzymes [e.g., Candida 
antarctica lipase B (CALB), Candida antarctica lipase A (CALA) and $\mathrm{OPH}]$, covalently bound to the polymeric shell of metal mesoporous nanoparticles. These systems enabled two-step onepot dynamic kinetic resolution (DKR) of 1-phenylethylamine and a $\beta$-amino ester (ethyl 3-amino-3-phenylpropanoate) in organic solvents, and the degradation of organophosphate nerve agent (methyl parathion) in aqueous solution. In all cases high reaction yields ( $75 \%$ conversion) and enantiomeric excess ( $98 \%$ ee) were reached (Gao et al., 2020). Importantly, the nature and length of polymeric coats and linkers, as well as the size of the nanoparticles and the methodology used to tether the enzymes, have a direct effect on the activity and selectivity of the biocatalyst. As studied by the group of Prof. Manuel Ferrer, protein flexibility constrains can be modulated through cautious design of the material and the strength of the linkage between the enzyme and the polymer (Coscolín et al., 2018). Interestingly, they found that short and rigid polymeric linkers limit the flexibility and dynamics of the enzyme, reducing its activity with larger substrates.

\section{Giant amphiphiles}

Finally, another route for the fabrication of enzyme decorated polymer nanoparticles is based on the synthesis of the socalled "giant amphiphiles," used effectively in sensing applications and heterogeneous catalysis. This method relies on the selfassembly of amphiphilic enzyme-polymer conjugates, being the enzyme the polar headgroup and the synthetic polymers the nonpolar tail of the macromolecule (Figure 5D). The conjugates act as giant surfactants that form protein covered nanoparticles in aqueous solutions in a relatively easy manner (Delaittre et al., 2009). This approach manages to control the morphology of the nanostructure and the orientation of the enzyme, and at the same time preserves the stability and the activity of the biocatalyst. This system demands the modification of the protein at only one single point. Therefore, affinity approaches (biotin-streptavidin binding, cofactor reconstitution) (Boerakker et al., 2006), or site-selective covalent polymer conjugation are used. As usual, the conjugation approach affects the stability of the micelle and the protein orientation (Huang and Olsen, 2016). In a recent example, enzyme-poly( $N-(2-$ hydroxypropyl) methacrylate)) (PHPMA) conjugates were selfassembled through polymerization-induced coassembly (PICA) approach. The water-insoluble PHPMA was synthetized by ATRP using glucose oxidase (GOx)-Br and horseradish peroxidase (HRP)-Br macroinitiators. Thereafter, the GOx/HRP-PHPMA conjugates were assembled in situ into co-micelles during the polymerization reaction. The co-micelles showed 4.9-fold cascade activity enhancement compared to free enzymes, and were used for a fast glucose detection (Chiang et al., 2020). Other chemistries, i.e., CuAAC click chemistry, have lately been used for the generation of self-assembled bioconjugated nanoparticles (Bao et al., 2018).

\section{Encapsulation of enzymes in the core of polymeric hollow structures}

In many cases, supramolecular polymeric structures are exploited to form enzymatic nanoreactors by filling the interior of the self-assembled polymers with guest enzymes (Delaittre et al.,
2009) (Figure 6 and Table 3). Several polymeric architectures are being used for the encapsulation of enzymes: reverse micelles, polymersomes, PICsomes, and hydrogel nanoparticles. Although the catalytic activity can be altered by the confinement, mostly due to mass-transfer issues, this strategy can be interesting to protect them from the action of proteases and to avoid their aggregation.

\section{Reverse micelles}

Polymer-based reverse micelles (RMs) $(10-50 \mathrm{~nm})$ are spherical structures formed by surfactant aggregates (Figure 6A). The hydrophilic heads are oriented to the micelle core due to dipoledipole and ion-dipole interaction, whereas the hydrophobic tails are in contact with the surrounding organic solvent. The low amount of water added to the solvent is confined near to the polar heads forming a small "water pool" that facilities the immobilization of the enzyme and the possibility to carry out reactions with hydrophobic substrates (Biasutti et al., 2008). The hydrophobic polymer shell makes the micelle stable in organic solvents and prevents the enzyme from denaturation. Cationic cetyltrimethyl-ammoniumbromide (CTAB), anionic bis(2-ethylhexyl) sulfosuccinate (AOT) and nonionic polyoxyethylene sorbitan trioleate (Tween 85) are the most used amphiphilic polymers (Chen H. et al., 2008). Interestingly, it has been proven that some enzymes such as, $\alpha$-chymotrypsin (Moyano et al., 2010), lipases (Maiti et al., 2011) or horseradish peroxidase (Zhong et al., 2016) show enhanced catalytic properties when they are confined in reverse micelles. It has been proposed that this positive effect could be a consequence of the conformational changes suffered by the protein, the high concentration of substrates within the RM, or an altered hydration state of the active site of the enzyme (Moyano et al., 2010; Sintra et al., 2014; Gao et al., 2018). However, the principles behind the so-called enzyme "superactivity" have not been elucidated yet.

\section{Polymersomes}

Polymersomes (100-400 $\mathrm{nm})$ are vesicle-like structures with a large size variability, which bilayer membrane is composed of amphiphilic block copolymers that mimic nature liposomes (Matoori and Leroux, 2020) (Figure 6B). The encapsulation of the enzymes inside the polymersomes occurs in situ, while the supramolecular arrangement of the block copolymers takes place. These polymeric structures are attractive for studying enzymatic reactions because they provide protection to the enzyme, localized in the core, from harsh environmental conditions and can confine the reaction within the nanospace, with the possibility to design multi-compartment systems (Klermund et al., 2017). Indeed, the confinement of enzymes in such small volumes can reduce their $K_{\mathrm{m}}$ and increase their $k_{\text {cat }}$ (Chen et al., 2009). However, although this mechanism seems convenient from the perspective of the protein (there is no need of modification of the biomacromolecule), several issues are found. The assembly of the polymersomes in presence of the protein usually shows a low encapsulation efficiency and a high heterogeneity of the sample. Moreover, it is often difficult to control the permeability of the membrane of this sort of hybrids, 


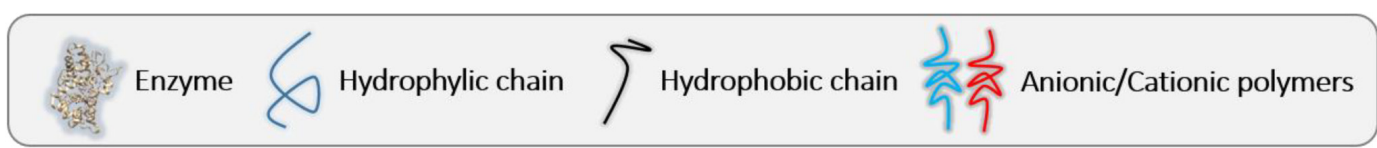

A

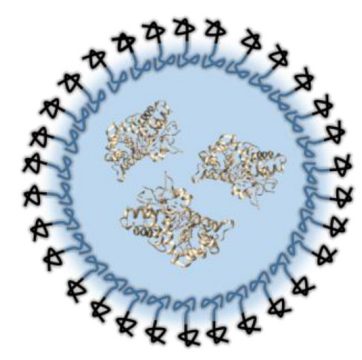

Reverse micelle enzyme hybrid
B

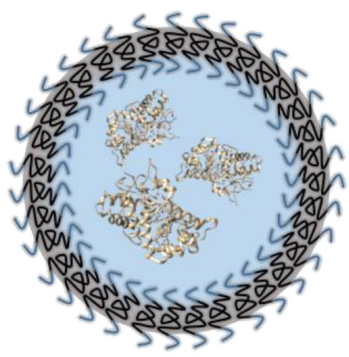

Polymersome enzyme hybrid
C

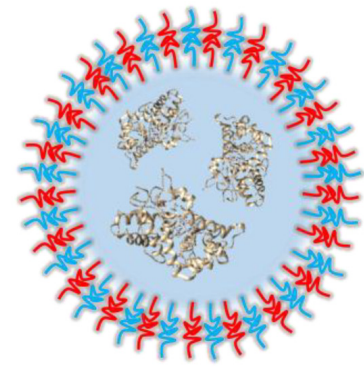

PICsome - enzyme hybrid

FIGURE 6 | Assembled enzyme-polymer supramolecular hybrids in which the enzyme is confined in the inner cavity of the structures. (A) Reverse micelle-enzyme hybrid. (B) Polymersome-enzyme hybrid. (C) PICsome-enzyme hybrid.

essential for the diffusion of reaction substrates and products (Blackman et al., 2018). For overcoming these issues, porous or stimuli-responsive membranes are used, as well as membrane channel proteins (Klermund et al., 2017). Hydrophilic polymers such as poly(2-methyl-2-oxazoline) (PMOXA), poly(ethylene glycol) (PEG), poly(isocyano-L-alanine(2-thiophen-3-ylethyl)amide) (PIAT), and hydrophobic polydimethylsiloxane and polystyrene (PS) are among the most used blocks for the synthesis of polymersomes (Belluati et al., 2019). Regarding the employed enzymes, this system is suitable for peroxidases, oxidases, dehydrogenases, and catalases (Gaitzsch et al., 2016).

\section{PICsomes}

Hydrophobicity is not the only noncovalent interaction used for the synthesis of nanometric polymeric capsules. There are several works focused on the formation of enzymeloaded polyion complex (PIC) vesicles (PICsomes) (Figure 6C), which are formed through the electrostatic interaction-mediated self-assembly between oppositely charged hydrophilic block copolymers (Anraku et al., 2010). The PICsome membrane is semipermeable and enables the uptake of the substrate of the enzyme and the release of products, while the enzymes are retained in the interior. Under mechanical stress, PICsomes tend to disassemble but, after the removal of perturbations, they have the ability to spontaneously reassemble, which is a good chance for re-encapsulating enzymes. Lately, PICsomes have been used for the successful immobilization of asparaginase (Sueyoshi et al., 2017) and $\beta$-Galactosidase (Anraku et al., 2016), with potential usefulness in delivery applications.

\section{MOF-enzyme nanohybrids}

Enzymes can be immobilized in the porous network of nanoscale coordination polymers $(\mathrm{N})$, better known as polymerbased metal organic frameworks (MOFs) (500 nm-2 $\mu \mathrm{m}$ ). NCPs are synthetized in presence of organic solvents and high temperatures and thereafter mixed with the enzyme

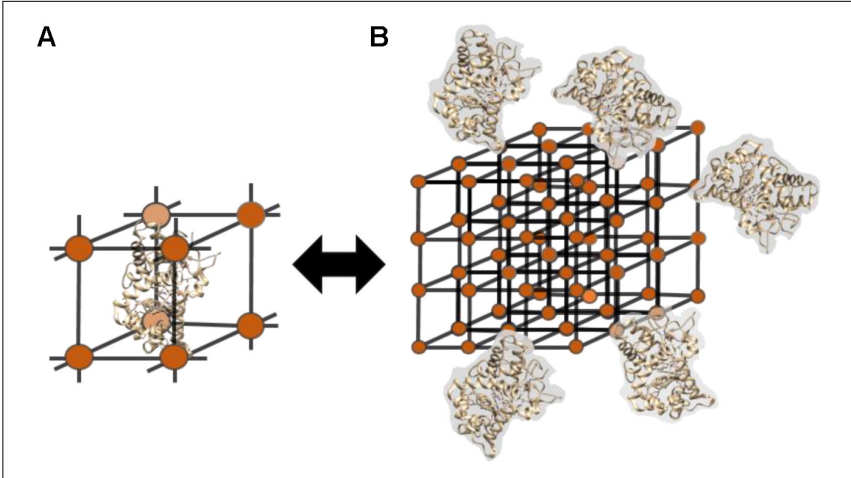

FIGURE 7 | Enzyme-MOF hybrids can be synthesized either by the infiltration of the protein inside the pores of the material $\mathbf{( A )}$ or through the immobilization of the enzyme on the surface of the organic framework (B).

in an aqueous phase to allow the enzyme infiltration into the pores (Chen et al., 2012) (Figure 7A). Alternatively, enzymes can be conjugated to the surface of the polymeric network by physical adsorption or covalent binding (Gkaniatsou et al., 2017; Liang et al., 2020) (Figure 7B). Finally, several methodologies such as coprecipitation (Lyu et al., 2014) or biomimetic biomineralization (Liang et al., 2016) allow the in situ incorporation of enzymes in the protective MOF structure. The selection of the most appropriate method for the synthesis of the hybrids must consider the synthesis conditions of the MOFs (usually not compatible with enzymes) and the pore size of the network (large enzymes might not fit in it).

Protein-NCP hybrids have been applied to a wide range of applications, such as sensing (Wang et al., 2016; Gao et al., 2017; Vinita et al., 2018; Wu et al., 2019; Xiong et al., 2020), microfluidic systems (Hu et al., 2020), removal of pollutants (Shen et al., 2019), photodynamic therapies (Cheng et al., 2016; Li et al., 2017; You 
et al., 2019; He et al., 2020), protein delivery (Chen et al., 2018; Yang et al., 2019; Zhang et al., 2019a; Alyami et al., 2020) or even for the optimization of the polymerase chain reaction (PCR) (Sun et al., 2020). Undoubtedly, the nature of the ligands and metals used for the synthesis of the MOFs has a direct impact on the final structure of the hybrid and eventually on the activity of the enzyme. In this regard, the porosity of the MOF is a key factor that can be tuned selectively in the synthesis procedure. MOFs synthesized with divalent metals such as $\mathrm{Zn}^{2+}, \mathrm{Fe}^{2+}$, and $\mathrm{Cu}^{2+}$ and imidazole-derived ligands, are the most employed for enzyme immobilization [see examples with catalase (Liang et al., 2019; Li et al., 2020), lipase (He H. et al., 2016; Pitzalis et al., 2018), HRP (Wu et al., 2017), cytochrome c (Zhang et al., 2017), $\beta$-galactosidase (Chen et al., 2018), and caspase-3 (CP-3) (Chen et al., 2018) collected in Table 3].

Finally, it is worth mentioning that also covalent organic frameworks (COFs) have currently been used as support materials for enzyme immobilization. In a very recent article, Li et al. (2020) achieved enzyme-COF capsules (co-immobilizing catalase and glucose oxidase by encapsulation). They used a MOF (ZIF-90 or Zeolitic Pyrimidine Framework, ZPF-2) structure as sacrificial template to make COF capsules. COFs provide an alternative with high porosity, stability, and readily engineered functionality to the formation of enzyme-polymer hybrids. The large porosity of COFs makes them suitable as platform for the enzyme, favoring the mass transfer of the substrate and the conformational freedom of the enzyme. Albeit this is a very recent approach applied to the field of enzyme-polymer hybrids, we do foresee the development of highly interesting enzyme-COF hybrids in the coming years due to the advantageous features that COF networks can provide to the hybrid system.

\section{Assembly of Enzyme-Polymer Hybrids Into Microstructures}

The embedment of enzymes into micro- or macroscopic polymeric structures has several benefits. Usually, the larger the hybrid, the better the recycling potential is. This fact improves substantially the overall economy of the process for a particular biocatalytic procedure. Compared to macrostructures, microscaled polymers usually show lower diffusion issues and fairly good upscaling capacity, which makes them one of the best options for the design of biocatalytic bioreactors (see collated examples in Table 4). In this section, we focus our attention on enzyme hybrids fabricated with micrometric polymeric hydrogels, layer-by-layer wise assembled enzyme microparticles, crosslinking polymers, and electrospun polymeric fibers (illustrations in Figure 8).

\section{Enzyme Hydrogel Microhybrids}

Polymeric hydrogels are three-dimensional polymeric network structures composed by natural or synthetic polymers with the ability to soak up high amounts of water and swell. The water absorption capability arises from hydrophilic groups (e.g., - $\mathrm{OH}$, $-\mathrm{CONH}_{2}$, and $-\mathrm{SO}_{3} \mathrm{H}$ ) in the structure, and the swelling behavior is related to the crosslinked structure, built by covalent and non-covalent bonds. Importantly, this architecture provides stability to the biomolecules, as well as high enzyme loading capacities (Hamidi et al., 2008) (Figure 8A). Hydrogels with a wide range of sizes can be targeted, ranging from $10 \mathrm{~nm}$ of the SENs, above described, to macroscopic enzyme-loaded sponges (Zhang et al., 2020), which are not in the focus of this review. The catalytic reaction rates of the latter are lower due to diffusion impairment caused by the polymer network. In contrast, the substrate/product diffusion path in enzyme-hydrogel microhybrids is shortened and, as consequence, the substrate is more rapidly exposed to the enzyme. Among the natural polymers, alginate, dextran, gelatin, chitosan, and agarose are the most studied ones due to their non-toxicity, biocompatibility, biodegradability, renewability, and the availability of seating numerous reactive sites (Beldengrün et al., 2018; Bilal and Iqbal, 2019b). The most employed synthetic polymers for the fabrication of hydrogel microparticles are poly(vinyl alcohol) (PVA), polyethyleneimine (PEI), polyvinylpyrrolidone (PVP), polyethyleneglycol (PEG), and poly( $N$-isopropylacrylamide) (PNIPAAM) (Pachioni-Vasconcelos et al., 2016). The synthesis procedure of the hybrids is very diverse. Proteins can be decorated with exogeneous reactive groups that will eventually be used to anchor the preformed polymeric network (Ji et al., 2016). For this aim, the use of click chemistry (e.g., sequential thiol-ene and bio-orthogonal tetrazine-norbornene click reactions) to control the synthesis of the hybrids can be an appreciated tool (Jivan et al., 2016). Alternatively, the direct mixture of preformed hydrogel microparticles with the enzyme solution has led to interesting microscopic hydrogels in which enzymes remain entrapped through weak interactions (Zhou et al., 2019). Recently, enzyme loaded hydrogel microparticles have been employed for the development of biosensors and enzyme-driven micromotors (Biswas et al., 2017; Keller et al., 2018).

\section{Layer-by-Layer Wise Assembled Enzyme-Polymer Microhybrids}

Layer-by-layer (LbL) deposition of ionic polymers is a commonly used methodology for the formation of micrometric hybrid biocatalysts. The fabrication consists in oppositely charged polyelectrolytes that assemble layer-wise on solid supports, usually a charged surface or an inorganic sacrificial template. This technique is conveniently explored for enzyme immobilization due to the mild conditions utilized in the assembly procedure, that help preserving enzyme folding and hence their stability (Figure 8B). It enables the on-demand design of the composition, thickness, charge, and permeability of the formed particles or films. Different micrometric designs for enzyme immobilization have been synthetized by LbL, such as microspheres, capsules, and hollow capsules (Sakr and Borchard, 2013). The most utilized ionic polymers are polystyrene sulfonate (PSS), poly(allylamine hydrochloride) (PAH), poly(ethylene imine) (PEI), and alginate (polysaccharide), which are usually combined with enzymes (typically catalase, glucose oxidase, $\alpha$-chemotrypsin or $\beta$ glucosidase). As mentioned above, inorganic particles (mainly made of calcium carbonate) with embedded enzymes are mainly used as sacrificial templates (Yu et al., 2005; Karamitros et al., 2013; Parakhonskiy et al., 2014). However, in a very interesting example, Caruso and coworkers developed a smooth and productive enzyme encapsulation strategy that consisted of the 
TABLE 4 | Summary of the most relevant examples of enzyme-polymer microhybrids.

\begin{tabular}{|c|c|c|c|c|c|c|c|}
\hline Structure & $\begin{array}{l}\text { Non-enzymatic } \\
\text { component }\end{array}$ & Enzyme & $\begin{array}{l}\text { Immobilization } \\
\text { method }\end{array}$ & Hybrid size & $\begin{array}{l}\text { Characteristics } \\
\text { (regarding activity) }\end{array}$ & Application & References \\
\hline \multirow[t]{4}{*}{ Hydrogels } & $\mathrm{PEG}^{3}$ & $\operatorname{Lac}^{15}$ & Entrapment & Macro & Six cycles (100\%) & $\begin{array}{l}\text { Polymerization } \\
\text { hydroquinone }\end{array}$ & Zhang et al., 2020 \\
\hline & $\begin{array}{l}\text { PEG, dithiothreitol } \\
\text { (DTT) }\end{array}$ & $\begin{array}{l}\text { ALP'16, } \\
\text { GOx }^{17}\end{array}$ & $\begin{array}{l}\text { Covalent binding } \\
\text { (Click chem) }\end{array}$ & 9-32 $\mu \mathrm{m}$ & $\begin{array}{l}\text { [Enzyme] dependent } \\
\text { increase }\end{array}$ & $\begin{array}{l}\text { Model for tissue } \\
\text { engineering, drug } \\
\text { delivery, and } \\
\text { biosensing }\end{array}$ & Jivan et al., 2016 \\
\hline & PEGDA ${ }^{5} /$ Dextran & $\mathrm{CAT}^{18}$ & Entrapment & $20 \mu \mathrm{m}$ & $\begin{array}{l}52 \% \text { of the original after } \\
\text { UV exposure }\end{array}$ & Micromotor & Keller et al., 2018 \\
\hline & Alginate & LOx ${ }^{19} /$ CAT & Entrapment & $11 \mu \mathrm{m}$ & 20 cycles $(100 \%)$ & Lactate sensing & Biswas et al., 2017 \\
\hline $\begin{array}{l}\mathrm{LbL}^{1} \\
\text { microparticle }\end{array}$ & $\begin{array}{l}\text { Poly dextran/poly- } \\
\text { L-arginine }\end{array}$ & $\mathrm{ASN}^{20}$ & Encapsulation (LbL) & $1-2 \mu \mathrm{m}$ & $\begin{array}{l}\text { Slightly enhanced } \\
\text { thermostability }\end{array}$ & Model for therapy & $\begin{array}{l}\text { Karamitros et al., } \\
2013\end{array}$ \\
\hline \multirow{2}{*}{ CLEPCs $^{2}$} & Imidazole-PAA ${ }^{6}$ & GOx & $\begin{array}{l}\text { Encapsulation and } \\
\text { affinity binding }\end{array}$ & $400-900 \mathrm{~nm}$ & $\begin{array}{l}\text { Slight decrease and } \\
\text { high thermostability }\end{array}$ & $\begin{array}{l}\text { Model for } \\
\text { biocatalysis }\end{array}$ & $\begin{array}{l}\text { Rodriguez- } \\
\text { Abetxuko et al., } \\
2019 a\end{array}$ \\
\hline & $\begin{array}{l}\text { Agar, chitosan, } \\
\text { dextran and gum } \\
\text { arabic }\end{array}$ & $\alpha$-amylase & $\begin{array}{l}\text { Covalent } \\
\text { (biopolymers } \\
\text { oxidized) }\end{array}$ & $\mathrm{NA}^{*}$ & Higher activity retention & $\begin{array}{l}\text { Model of } \\
\text { biocompatible } \\
\text { CLEAs }{ }^{31}\end{array}$ & Nadar et al., 2016 \\
\hline \multirow[t]{3}{*}{ Polymer fibers } & $\mathrm{PAN}^{7} / \mathrm{MMT}^{8} / \mathrm{GO}^{9}$ & Lac & Adsorption & ca. d. $200 \mathrm{~nm}$ & $\begin{array}{l}39 \% \text { of removal. GO } \\
\text { increased stability }\end{array}$ & Bioremediation & Wang et al., 2014 \\
\hline & $\mathrm{PMMA}^{10} / \mathrm{Fe}_{3} \mathrm{O}_{4}$ & Lac & $\begin{array}{l}\text { Covalent binding } \\
\left(\mathrm{EDC}^{25} / \mathrm{NHS}^{26}\right) \text {, } \\
\text { entrapment }\end{array}$ & ca. d. $500 \mathrm{~nm}$ & $\begin{array}{l}\text { High activity retained } \\
\text { upon } 40 \text { days store }\end{array}$ & Bioremediation & Zdarta et al., 2019a \\
\hline & Chitosan-gelatine & $\mathrm{HRP}^{23}$ & $\begin{array}{l}\text { Covalent binding } \\
\text { (GA) }\end{array}$ & ca. d. $80 \mathrm{~nm}$ & $\begin{array}{l}\text { Activity preserved. } \\
\text { LOD }^{28} 0.05 \mathrm{mM}\end{array}$ & $\begin{array}{l}\text { Electrochemical } \\
\text { biosensor of } \mathrm{H}_{2} \mathrm{O}_{2}\end{array}$ & Teepoo et al., 2017 \\
\hline
\end{tabular}

*Not available; ${ }^{1}$ layer-by-Layer; ${ }^{2}$ cross-linked enzyme-polymer conjugates; ${ }^{3}$ polyethylene glycol; ${ }^{4}$ poly(N-isopropylacrylamide); ${ }^{5}$ poly(ethylene glycol) diacrylate; ${ }^{6}$ poly(acrylic acid); ${ }^{7}$ poly(acrylonitrile); ${ }^{8}$ montmorillonite; ${ }^{9}$ graphene oxide; ${ }^{10}$ poly(methyl methacrylate); ${ }^{11}$ poly(L-lactide-co-e-caprolactone); ${ }^{12}$ poly(3,4-ethylenedioxythiophene); ${ }^{13}$ polystyrene; ${ }^{14}$ poly(styrene-co-maleic anhydride); ${ }^{15}$ laccase; ${ }^{16}$ alkaline phosphatase; ${ }^{17}$ glucose oxidase; ${ }^{18}$ catalase; ${ }^{19}$ lipoxygenase; ${ }^{20}$ asparaginase; ${ }^{21}$ organophosphate hydrolase; ${ }^{22}$ bovine carbon anhydrase; ${ }^{23}$ horseradish peroxidase; ${ }^{24}$ glutaraldehyde; ${ }^{25} 1$-Ethyl3-(3-dimethylaminopropyl)carbodiimide; ${ }^{26} \mathrm{~N}$-hydroxysuccinimide; ${ }^{27}$ apparent Michaelis constant of adsorption and entrapment; ${ }^{28}$ limit of detection;

${ }^{29} 1$-ethyl-3-methyllimidazolium acetate; ${ }^{30}$ organophosphorus; ${ }^{31}$ cross-linked enzyme aggregates.

formation of the LbL assembly on the surface of enzyme crystals, skipping the use of templates. With this approach, the enzymes are hydrated after the assembly process and remain trapped inside the capsule (Caruso et al., 2000).

\section{Cross-Linked Enzyme-Polymer Conjugates}

The synthesis of cross-linked enzyme aggregates (CLEAs) is a widely employed enzyme immobilization method. Basically, enzymes are covalently connected by a cross-linking agent. The most used cross-linker is glutaraldehyde (GA) due to its high conversion efficiencies, low cost, and high market availability (Velasco-Lozano et al., 2016). However, the density of accessible lysine residues is sometimes low for an effective cross-linking. In this case, additives such as polymers or protein feeders are commonly introduced, e.g., PEIs (López-Gallego et al., 2005), PEI-sulfate dextran (Wilson et al., 2004), dodecyl aldehyde (Guimarães et al., 2018), bovine serum albumin (BSA) (Torabizadeh et al., 2014; Amaral-Fonseca et al., 2018), egg albumin (Šulek et al., 2011), poly-lysine (Yamaguchi et al., 2011), and soy protein isolate (SPI) (Araujo-Silva et al., 2018). 


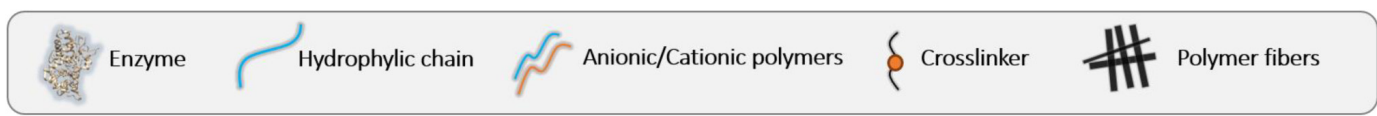

A

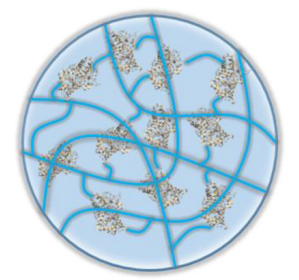

Enzyme-hydrogel microparticle

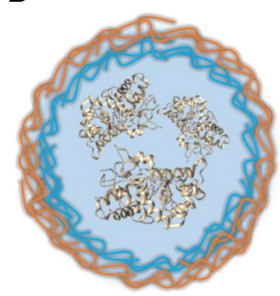

Layer-by-layer assembled microparticle
C

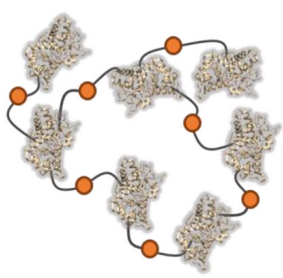

CLEA/MOEA
D

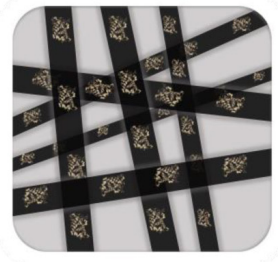

Electrospun fibers

FIGURE 8 | Schematic illustration of enzyme-polymer microhybrids described in this work. (A) Enzyme-hydrogel microparticles. (B) Microparticles or vesicles formed by LbL assembly. (C) CLEAs or MOEAs. (D) Enzyme-polymer fiber hybrids.

However, several issues such as its high toxicity and reactivity have been found with the use of GA as crosslinking agent. For this reason, (bio)polymers have been attempted in the last years, giving rise to cross-linked enzyme-polymer conjugates (CLEPCs), e.g., dextran-polyaldehyde (DP) (Mateo et al., 2004; Sahutoglu and Akgul, 2015), gum Arabic (Jin et al., 2019), chitosan (Nadar et al., 2016), and ethylene glycol-bis[succinic acid $N$-hydroxysuccinimide] (EG-NHS) (Rehman et al., 2016). Recently, our group has developed a methodology for the cross-linking of single enzyme nanogels, triggered by metalimidazole coordination, resulting the so-called metal-organic enzyme aggregates (MOEAs). High enzyme loadings and low diffusional issues of MOEAs make them extraordinary candidates for biocatalysis applications (Rodriguez-Abetxuko et al., 2019a) (see collated examples with main results in Table 4).

\section{Enzyme-Polymer Fiber Hybrids}

Electrospun nanofibers are alternative polymeric structures that make use of electrospinning technology (Cleeton et al., 2019) to form large fibers. The most important features of the materials produced by electrospinning are the high degree of porosity (provided by the features of the polymer), the biocompatibility, and the high number of functional groups that can be displayed on the surface (mainly $-\mathrm{NH}_{2}$ and $\mathrm{OH})$. Thus, this method significantly increases the enzyme loads in comparison with conventional supports. On the last two decades, this technique has been employed to immobilize diverse (bio)molecules, including enzymes, in applications such as biosensors (Teepoo et al., 2017), pollution control (Jun et al., 2020), or bioreactors (Sakai et al., 2008) (Figure 8D). So far, two methodologies are followed for the fabrication of the enzymenanofiber hybrids: entrapment (in situ immobilization) and surface attachment (adsorption or covalent binding). Despite the drawbacks of immobilization by adsorption, i.e., reliance on the composition of the enzyme and protein leakage, it is an excellent approach that enables the increase of the activity and reusability of the enzyme (Wang Q. et al., 2013; Wang et al., 2006, 2014). On the other hand, covalent binding offers an improvement of the enzyme-support stability to a larger extent (Li et al., 2007; Feng et al., 2012, 2013; Zhang et al., 2014). In a recent study, Zdarta et al. (2019a) compared both methods of immobilization using polymeric fibers. They employed poly(L-lactic acid)-co-poly( $\varepsilon$ caprolactone) (PLCL) electrospun nanofibers to immobilize laccase by either entrapment or adsorption approach for the biodegradation of hazardous pollutants from wastewaters. They observed an increase of the affinity (lower $K_{\mathrm{m}}{ }^{\text {app}}$ ) of the adsorbed enzyme toward the substrate. Yet, the efficiency of the removal of pollutants by this hybrid was lower, mainly due to the deactivation of the enzyme and its leakage from the support. When covalent binding and entrapment methods were compared in terms of stability, they observed also significant differences. Both showed a significant enhancement with respect of free enzyme, which lost half of its activity after 20 days. However, while the hybrid fabricated through the covalent approach showed the $75 \%$ of the initial activity after 40 days of storage, the entrapped enzyme conserved $90 \%$ of the activity (Zdarta et al., 2019a). Other polymeric fibers such as poly(vinyl alcohol) (PVA) (Dinçer and Telefoncu, 2007), polyamide 6 (PVA/PA6) (Feng et al., 2014), polyacrylonitrile (PAN) (Wang et al., 2014), amidoxime polyacrylonitrile (AOPAN) (Zhang et al., 2014), and poly(3,4-ethylenedioxythiophene) (PEDOT)/PAN (Çetin and Camurlu, 2018) have been explored as supports for enzymes.

\section{Assembly of Enzyme-Polymer Hybrids Into Macrostructures}

Finally, in this last section, we highlight the use of macroassembled polymers into monoliths and continuous films as platforms for enzyme immobilization (Figure 9 and Table 5). The size of these materials provides the hybrids with good mechanical properties, expanding their applicability.

\section{Polymer Monoliths-Enzyme Hybrids}

Polymer monoliths are very interesting macrostructures developed in 1990s, mainly based on methacrylates, acrylates, and styrenes. The polymerization is performed in templates such as rod polymer for chromatographic columns (Watanabe et al., 2009; Li et al., 2010; Duan et al., 2020), disks (Lin et al., 2020), and microfluidic channels (Knob et al., 2016; Parker et al., 2019; 
TABLE 5 | Summary of the most relevant examples of polymer-enzymes macrostructures.

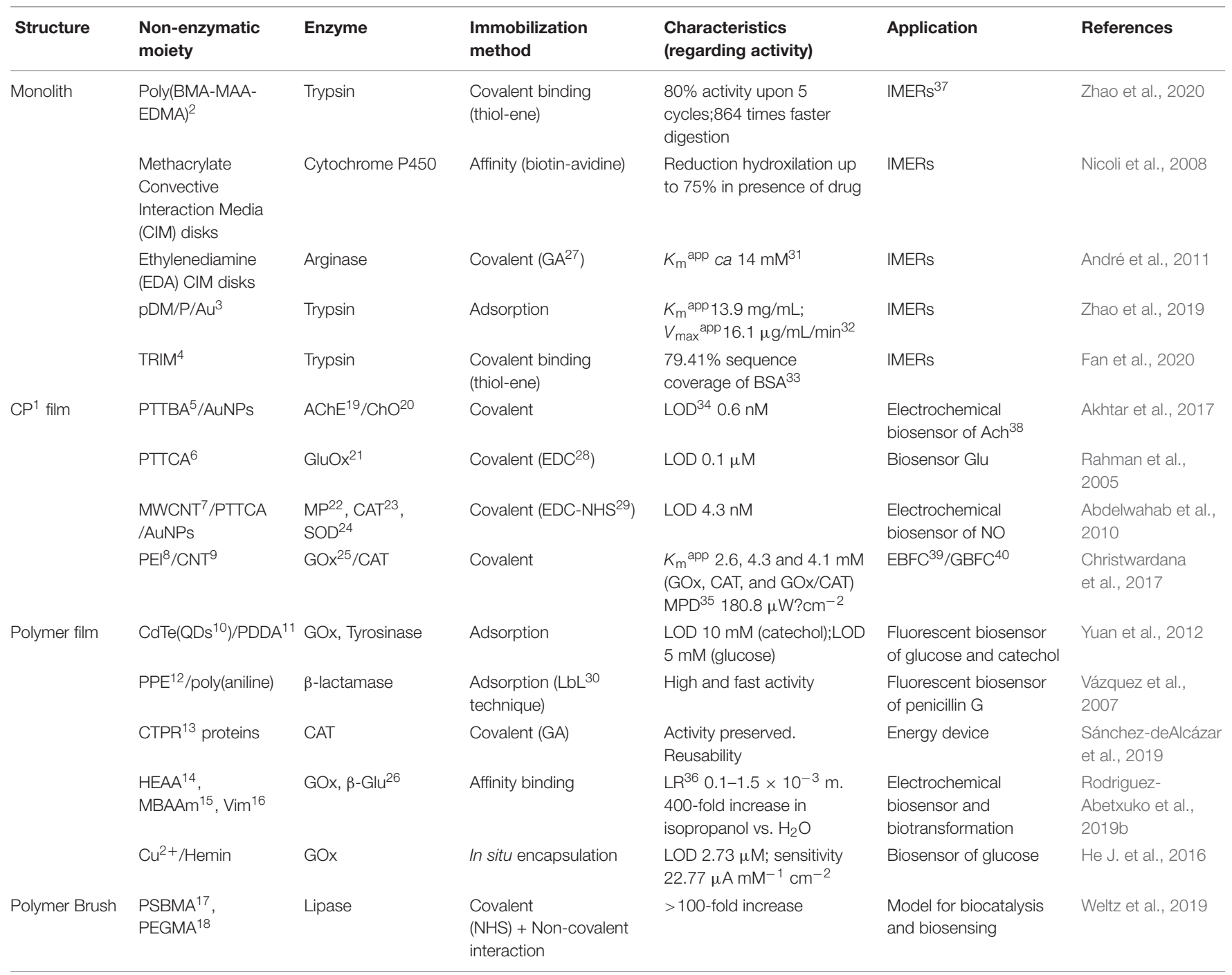

${ }^{1}$ Conducting polymers; ${ }^{2}$ butyl methacrylate- $\alpha$-methacrylic acid-ethylene glycol dimethacrylate; ${ }^{3}$ cryogel composite; ${ }^{4}$ trimethylo/propane trimethacrylate; ${ }^{5} 2,2: 5,2-$ terthiophene-3-(p-benzoic acid); ${ }^{6}$ Poly-5,2':5', $2^{\prime \prime}$-terthiophene-3'-carboxylic acid; 7 multi-walled carbon nanotubes; ${ }^{8}$ polyethylenimine; ${ }^{9}$ carbon nanotubes; ${ }^{10}$ quantum dots; ${ }^{11}$ poly(dimethyldiallylammonium chloride); ${ }^{12}$ polyphenyl ether; ${ }^{13}$ consensus tetratricopeptide repeat protein; ${ }^{14}$ hydroethylacrylamide; ${ }^{15} \mathrm{~N}, \mathrm{~N}^{\prime}$ methylenebisacrylamide; ${ }^{16}$ vinyl imidazole; ${ }^{17}$ poly(sulfobetaine methacrylate); ${ }^{18}$ poly(poly(ethylene glycol) methacrylate); ${ }^{19}$ acetylcholinesterase; ${ }^{20}$ cholinesterase; ${ }^{21}$ glutamate oxidase; ${ }^{22}$ microperoxidase; ${ }^{23}$ catalase; ${ }^{24}$ superoxide dismutase; ${ }^{25}$ glucose oxidase; ${ }^{26} \beta$-glucosidase; ${ }^{27}$ g/utaraldehyde; ${ }^{28} 1$-Ethyl-3-(3dimethylaminopropyl)carbodiimide; ${ }^{29} \mathrm{~N}$-hydroxysuccinimide; ${ }^{30}$ layer-by-layer; ${ }^{31}$ apparent Michaelis constant; ${ }^{32}$ maximam velocity; ${ }^{33}$ bovine serum albumin; ${ }^{34}$ limit of detection; ${ }^{35}$ maximum power density; ${ }^{36}$ linear range; ${ }^{37}$ immobilized monolith-enzyme reactor; ${ }^{38}$ acetylcholine; ${ }^{39}$ enzymatic biofuel cell; ${ }^{40} \mathrm{glucose}$ biofuel cell.

Zhu et al., 2019). Monoliths can be functionalized with different groups such as epoxy, aldehyde or alkene groups (Masini and Svec, 2017). These supports have been used for the stabilization of enzymes in both aqueous media and organic solvents ( $\mathrm{LV}$ et al., 2014; Wen et al., 2016a; Luo et al., 2019). However, the main drawback of polymer monoliths relies on the large size of their pores, which results in low enzyme loads. Fortunately, this limitation can be circumvented by grafting a polymer layer on the surface of the macropores of monoliths (Peterson et al., 2003; Li et al., 2014; Wen et al., 2016b).

Enzyme-monolith hybrids (Figure 9A) have a relevant impact in microfluidic applications (Logan et al., 2007; Krenkova et al., 2009; Meller et al., 2017; Cheng et al., 2019) and, in less extension, biosensors (Luo et al., 2019), and HPLC (Girelli and
Mattei, 2005). However, its preferential and successful application is as a bio-reactor platform for proteomic analysis (Peterson et al., 2002; Geiser et al., 2008; Sproß and Sinz, 2010; Calleri et al., 2011; Liang et al., 2011; Naldi et al., 2017; Han et al., 2019; Zhang et al., 2019). On a very recent example (Zhao et al., 2020), it has been shown a straightforward method for the fabrication of an immobilized monolith-enzymatic reactor (IMER) for proteome analysis (coupled to ESI-MS technique). The immobilization process was carried out by "thiol-ene" click chemistry. The thiol groups of the trypsin enzyme reacted with alkene groups of a polymer monolith fabricated with ethylene glycol dimethacrylate (EDMA) to form a thioether. Enzyme turned out to be very active with a $K_{\mathrm{m}}$ app of $2.1 \mathrm{mM}$, quite similar to that measured for the free enzyme $\left(K_{\mathrm{m}} 1.4 \mathrm{mM}\right)$. In 


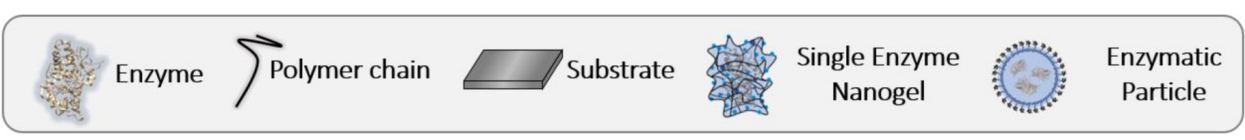

A

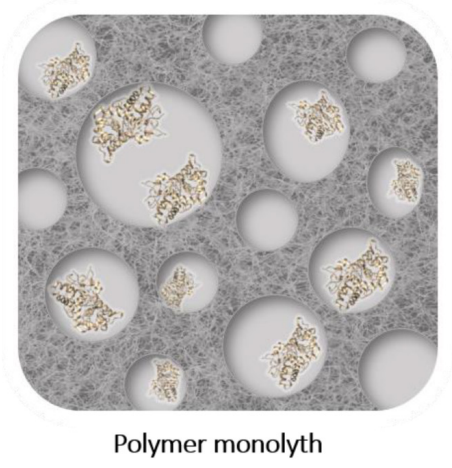

B

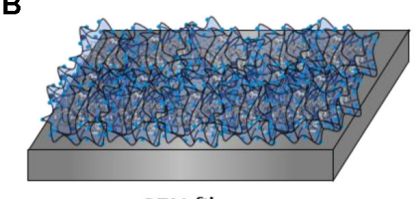

SEN film

D

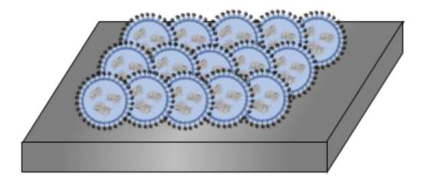

Microparticle film

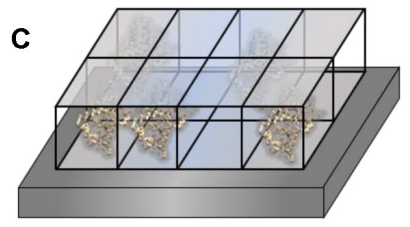

MOF film

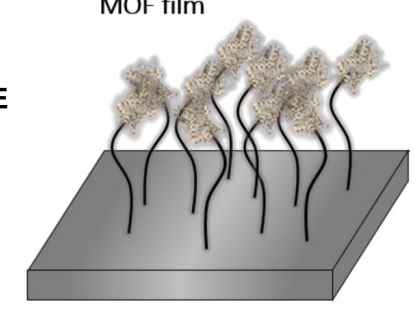

Brush film

FIGURE 9 | Schematic illustration of enzyme-polymer monoliths and enzyme-polymer film types formed following different approaches mentioned in this work: (A) polymer monoliths; (B) assembly of SENs; (C) assembly of MOFs; (D) assembly of microparticles; and (E) attachment to polymer brushes.

addition, the enzyme maintained the activity up to $80 \%$ after five cycles. In the same line, they extended their IMER design using trimethylolpropane trimethacrylate (TRIM), instead of EDMA, increasing the anchoring points of the support. Thus, they raised the enzymatic load and hence the specific activity of the hybrid (Fan et al., 2020; Wei et al., 2020) (details in Table 5). Also, IMERs have been applied for the immobilization of other enzymes involved in other pathologies such as arginase in cardiovascular diseases (André et al., 2011), acetylcholinesterase (AChE) in the treatment of Alzheimer disease (De Simone et al., 2019) or in metabolism studies using the cytochrome P450 enzyme (Nicoli et al., 2008).

\section{Enzyme-Polymer Films}

The application of enzyme-polymer films are rather relevant in distinct scientific areas and applications such as biosensors (Vázquez et al., 2007; Yuan et al., 2012), muti-enzymatic cascade reactions (Sharma et al., 2013; Farrugia et al., 2017), or enzymatic biofuel cells (EBFCs) (Chung et al., 2016; Christwardana et al., 2017). In particular, polymer-enzyme films-based biosensors have been widely studied as alternative to the traditional chemical methodologies. The assembly of enzyme-polymer hybrids in film fashion can be performed by simple deposition or drop casting (Rodriguez-Abetxuko et al., 2019b; Sánchez-deAlcázar et al., 2019), by spin-coating (Chen B. et al., 2008), by layer-by-layer approaches (Scodeller et al., 2014; Zhang et al., 2019b), by electrospinning (Henke et al., 2020), by dip-coating (Marquitan et al., 2020) or by Langmuir-Blodget technique (Qian et al., 2002). Smaller enzymepolymer hybrids, e.g., MOFs, particles or SENs, (Dong et al., 2018; Liu et al., 2018; Wang et al., 2018; Sureka et al., 2019; Henke et al., 2020), can be thereby deposited in continuous films to form responsive biocoatings (Figures 9B,C). For example, single enzyme nanogels of glucose oxidase are able to assemble into ordered and highly stable films by means of coordination polymers and divalent metals (Rodriguez-Abetxuko et al., 2019b). Also, $\mathrm{Cu}^{2+}$-based tyrosinase MOFs can be used to fabricate a bisphenol A biosensor (Wang et al., 2015; Lu et al., 2016).

\section{Use of conductive polymers}

Conducting polymers (CPs) have attracted the attention because they exhibit interesting properties for the development of biosensors (Marcus and Sutin, 1985). CPs have high electrical conductivity, low ionization potential, high electronic affinities, as well as optical properties. The most used systems are based on polyacetylene, polyaniline (PANI), polypyrrole (Ppy), polythiophene, poly ( $p$-phenylene), and poly (phenylene vinyl-ene). Successful CPs-based enzyme biosensors have been fabricated for the detection of biological molecules such as glutamic acid (Rahman et al., 2005; Kergoat et al., 2014), acetylcholine (Fenoy et al., 2020), and soluble gasses as NO (Abdelwahab et al., 2010), all of them associated to particular diseases. As an example, the adsorption of acetylcholinesterase $(\mathrm{AChE})$ and choline oxidase $(\mathrm{ChO})$ enzymes on a film of $\mathrm{Fe}_{2} \mathrm{O}_{3} \mathrm{NPs} /$ poly(3,4-ethylenedioxythiophene (PEDOT))-reduced graphene oxide (rGO)/modified fluorine doped tin oxide (FTO) electrode reported a detection limit of acetyl choline as low as $4 \mathrm{nM}$. The proposed sensor was applied to determine acetyl choline in serum samples from healthy and Alzheimer's patients. Since acetylcholine concentration is slightly lower in Alzheimer's patients than in healthy individuals $(5.0-7.8 \mathrm{nM}$ vs. $8.2-11.3 \mathrm{nM}$, respectively), this system is capable to discriminate both populations (Chauhan et al., 2017). In order to overcome the drawbacks related to enzyme immobilization (mainly related to 
protein leakage) and enhance the sensitivity, Akhtar et al. (2017) covalently co-immobilized both enzymes (AChE and $\mathrm{ChO}$ ). With this approach, the sensitivity was reduced significantly, reporting a detection limit of $c a .0 .6 \mathrm{nM}$ and a usability of 60 days maintaining the $91 \%$ of the sensitivity. Similarly, highly sensitive CP-based glucose biosensors, which are relevant for patients suffering from Diabetes's disease, have also been developed using glucose oxidase (GOx) enzyme. The use of GOx-loaded PtNPsPEDOT microspheres has shown the best reported sensor of PEDOT up to date (Piro et al., 2001; Nien et al., 2006; David et al., 2018; Liu et al., 2018).

\section{Use of polymeric brushes}

Aiming at modifying the surface of materials, i.e., electrodes or particles, the use of polymeric brushes can be an alternative to film deposition. Polymer brushes are long and flexible polymer chains, attached to surfaces or other polymer chains, with high grafting density (Figure 9E). The chemistry, the molecular weight, and the grafting density can be wisely tailored. These parameters may have an effect on the structure and hence the activity of the enzyme. Furthermore, polymeric brushes act as an extension of the surface into a third dimension, granting a high and tunable density of functional groups (epoxide, carboxylic acid, hydroxyl, aldehyde, and amine groups) that can be eventually used for the conjugation of enzymes (Jiang and Xu, 2013). Several publications have pointed out that hydrophilic or zwitterionic polymer brushes create favorable microenvironments for catalysis (Weltz et al., 2019). However, there is still some work to do in the fabrication of efficient enzyme-polymer brush systems. The amount of reactive groups within the polymer brushes should be optimized for each case, as the high density of those leads to a reduced degree of conformational freedom of the enzyme, which is generally translated to lower bioactivities (Jiang and Xu, 2013).

\section{CONCLUSION AND OUTLOOK}

In this review, we have brought together different approaches to enhance the stabilization or increase the activity of enzymes using tunable polymers as non-catalytic supporting materials. With different examples, we have demonstrated that the polymer is usually more than a mere support. Polymers can be used to protect enzymes from denaturation, to increase the bioactivity through beneficial interactions, to concentrate the enzymes in small volumes, to confine

\section{REFERENCES}

Abdelwahab, A. A., Koh, W. C. A., Noh, H.-B., and Shim, Y.-B. (2010). A selective nitric oxide nanocomposite biosensor based on direct electron transfer of microperoxidase: removal of interferences by co-immobilized enzymes. Biosens. Bioelectron. 26, 1080-1086. doi: 10.1016/j.bios.2010.08.070

Adrio, J. L., and Demain, A. L. (2014). Microbial enzymes: tools for biotechnological processes. Biomolecules 4, 117-139. doi: 10.3390/ biom 4010117 the enzymes in favorable environments, or to ease the recyclability of the enzyme. These hybrids are built up as a result of the careful selection of each component, i.e., enzyme and polymer, and the strategy utilized for their combination. The current synthesis methods have facilitated the control over the amount, position of the conjugation-site, and orientation of the immobilized enzymes, as well as the molecular architecture of the resultant hybrid. Furthermore, we have shown that nanohybrids are suitable for nanomedicine applications, mainly due to an easier transport, biocompatibility, and more adequate delivery inside the body. Moreover, the high enzyme/polymer ratio content showed by enzymepolymer conjugates (EPCs), single enzyme nanogels (SENs), giant amphiphiles or reverse micelles make them attractive for novel applications. On the other hand, bigger structures, such as polymer monoliths or films, have a more relevant impact as reactors or biosensors, respectively. All in all, new, refined, and sophisticated hybrid structures with novel functionalities are sought. However, the reusability and storage of the immobilized enzymes is still the limiting factor for a cost-effective applicability and commercialization of these systems. Finally, we anticipate the emergence of new and appealing approaches in the field of enzyme-polymer hybrids as novel polymeric architectures and synthesis methodologies are being developed.

\section{AUTHOR CONTRIBUTIONS}

AR-A and DS revised the literature and wrote the manuscript. PM designed the figures. AB supervised the work, designed the figures, and wrote the manuscript.

\section{FUNDING}

This work is in the framework of a project that has received funding from the Spanish Ministry of Economy and Competitiveness (MINECO) and FEDER funds in the frame of "Plan Nacional - Retos para la Sociedad" call with the grant references MAT2017-88808-R and PID2019-110239RBI00. This work was performed under the Maria de Maeztu Units of Excellence Programme - MDM-2016-0618. AB thanks the Spanish Research Agency (AEI) for the funds within Ramón y Cajal programme (RYC2018-025923-I). AR-A thanks the Basque Government for his Ph.D. fellowship (PRE_2019_2_0147).

Akhtar, M. H., Hussain, K. K., Gurudatt, N. G., and Shim, Y. B. (2017) Detection of $\mathrm{Ca} 2+$-induced acetylcholine released from leukemic T-cells using an amperometric microfluidic sensor. Biosens. Bioelectron. 98, 364-370. doi: 10.1016/j.bios.2017.07.003

Alyami, M. Z., Alsaiari, S. K., Li, Y., Qutub, S. S., Aleisa, F. A., Sougrat, R., et al. (2020). Cell-Type-specific CRISPR/Cas9 delivery by biomimetic metal organic frameworks. J. Am. Chem. Soc. 142, 1715-1720. doi: 10.1021/jacs.9b11638

Amaral-Fonseca, M., Kopp, W., Giordano, R., Fernández-Lafuente, R., and Tardioli, P. (2018). Preparation of magnetic cross-linked amyloglucosidase 
aggregates: solving some activity problems. Catalysts 8:496. doi: 10.3390/ catal8110496

André, C., Herlem, G., Gharbi, T., and Guillaume, Y. C. (2011). A new arginase enzymatic reactor: development and application for the research of plantderived inhibitors. J. Pharm. Biomed. Anal. 55, 48-53. doi: 10.1016/j.jpba.2011. 01.003

Anraku, Y., Kishimura, A., Kamiya, M., Tanaka, S., Nomoto, T., Toh, K., et al. (2016). Systemically injectable enzyme-loaded polyion complex vesicles as in vivo nanoreactors functioning in tumors. Angew. Chem. Int. Edn. 55, 560565. doi: 10.1002/anie.201508339

Anraku, Y., Kishimura, A., Oba, M., Yamasaki, Y., and Kataoka, K. (2010). Spontaneous formation of nanosized unilamellar polyion complex vesicles with tunable size and properties. J. Am. Chem. Soc. 132, 1631-1636. doi: 10.1021/ ja908350e

Araujo-Silva, R., Mafra, A., Rojas, M., Kopp, W., Giordano, R., FernandezLafuente, R., et al. (2018). Maltose production using starch from cassava bagasse catalyzed by cross-linked $\beta$-amylase aggregates. Catalysts 8:170. doi: 10.3390/ catal 8040170

Arnold, F. H. (2018). Directed Evolution: Bringing New Chemistry to Life. Angew. Chem. Int. Edn. 57, 4143-4148. doi: 10.1002/anie.201708408

Assarsson, A., Pastoriza-Santos, I., and Cabaleiro-Lago, C. (2014). Inactivation and adsorption of human carbonic anhydrase II by nanoparticles. Langmuir 30, 9448-9456. doi: 10.1021/la501413r

Averick, S., Mehl, R. A., Das, S. R., and Matyjaszewski, K. (2015). Well-defined biohybrids using reversible-deactivation radical polymerization procedures. J. Control. Release 205, 45-57. doi: 10.1016/j.jconrel.2014.11.030

Baker, S. L., Munasinghe, A., Murata, H., Lin, P., Matyjaszewski, K., Colina, C. M., et al. (2018). Intramolecular interactions of conjugated polymers mimic molecular chaperones to stabilize protein-polymer conjugates. Biomacromolecules 19, 3798-3813. doi: 10.1021/acs.biomac.8b00927

Baker, S. L., Murata, H., Kaupbayeva, B., Tasbolat, A., Matyjaszewski, K., and Russell, A. J. (2019). Charge-preserving atom transfer radical polymerization initiator rescues the lost function of negatively charged protein-polymer conjugates. Biomacromolecules 20, 2392-2405. doi: 10.1021/acs.biomac.9b00379

Balcão, V. M., and Vila, M. M. D. C. (2015). Structural and functional stabilization of protein entities: State-of-the-art. Adv. Drug Deliv. Rev. 93, 25-41. doi: 10. 1016/j.addr.2014.10.005

Bao, C., Yin, Y., and Zhang, Q. (2018). Synthesis and assembly of laccase-polymer giant amphiphiles by self-catalyzed CuAAC click chemistry. Biomacromolecules 19, 1539-1551. doi: 10.1021/acs.biomac.8b00087

Barbosa, O., Ortiz, C., Berenguer-Murcia, A., Torres, R., Rodrigues, R. C., and Fernandez-Lafuente, R. (2015). Strategies for the one-step immobilizationpurification of enzymes as industrial biocatalysts. Biotechnol. Adv. 33, 435-456. doi: 10.1016/j.biotechadv.2015.03.006

Bayramoglu, G., Yilmaz, M., and Arica, M. Y. (2010). Reversible immobilization of laccase to poly(4-vinylpyridine) grafted and $\mathrm{Cu}(\mathrm{II})$ chelated magnetic beads: biodegradation of reactive dyes. Bioresour. Technol. 101, 6615-6621. doi: 10. 1016/j.biortech.2010.03.088

Beldengrün, Y., Aragon, J., Prazeres, S. F., Montalvo, G., Miras, J., and Esquena, J. (2018). Gelatin/maltodextrin water-in-water (W/W) emulsions for the preparation of cross-linked enzyme-loaded microgels. Langmuir 34, 97319743. doi: 10.1021/acs.langmuir.8b01599

Belluati, A., Craciun, I., Meyer, C. E., Rigo, S., and Palivan, C. G. (2019). Enzymatic reactions in polymeric compartments: nanotechnology meets nature. Curr. Opin. Biotechnol. 60, 53-62. doi: 10.1016/j.copbio.2018.12.011

Beloqui, A., Baur, S., Trouillet, V., Welle, A., Madsen, J., Bastmeyer, M., et al. (2016). Single-molecule encapsulation: a straightforward route to highly stable and printable enzymes. Small 12, 1716-1722. doi: 10.1002/smll.201503405

Beloqui, A., and Cortajarena, A. L. (2020). Protein-based functional hybrid bionanomaterials by bottom-up approaches. Curr. Opin. Struct. Biol. 63, 74-81. doi: 10.1016/j.sbi.2020.04.005

Beloqui, A., Kobitski, A. Y., Nienhaus, G. U., and Delaittre, G. (2018). A simple route to highly active single-enzyme nanogels. Chem. Sci. 9, 1006-1013. doi: 10.1039/C7SC04438K

Biasutti, M. A., Abuin, E. B., Silber, J. J., Correa, N. M., and Lissi, E. A. (2008). Kinetics of reactions catalyzed by enzymes in solutions of surfactants. $A d v$. Colloid Interf. Sci. 136, 1-24. doi: 10.1016/j.cis.2007.07.001
Bilal, M., and Iqbal, H. M. N. (2019a). Chemical, physical, and biological coordination: an interplay between materials and enzymes as potential platforms for immobilization. Coord. Chem. Rev. 388, 1-23. doi: 10.1016/j.ccr. 2019.02.024

Bilal, M., and Iqbal, H. M. N. (2019b). Naturally-derived biopolymers: potential platforms for enzyme immobilization. Int. J. Biol. Macromol. 130, 462-482. doi: 10.1016/j.ijbiomac.2019.02.152

Biswas, A., Bornhoeft, L. R., Banerjee, S., You, Y. H., and McShane, M. J. (2017). Composite hydrogels containing bioactive microreactors for optical enzymatic lactate sensing. ACS Sens. 2, 1584-1588. doi: 10.1021/acssensors.7b00648

Biswas, A., Joo, K., Liu, J., Zhao, M., Fan, G., Wang, P., et al. (2011). Endoproteasemediated intracellular protein delivery using nanocapsules. ACS Nano 5, 1385 1394. doi: 10.1021/nn1031005

Blackman, L. D., Varlas, S., Arno, M. C., Houston, Z. H., Fletcher, N. L., Thurecht, K. J., et al. (2018). Confinement of therapeutic enzymes in selectively permeable polymer vesicles by polymerization-induced self-assembly (PISA) reduces antibody binding and proteolytic susceptibility. ACS Cent. Sci. 4, 718-723. doi: 10.1021/acscentsci.8b00168

Boerakker, M. J., Botterhuis, N. E., Bomans, P. H. H., Frederik, P. M., Meijer, E. M., Nolte, R. J. M., et al. (2006). Aggregation behavior of giant amphiphiles prepared by cofactor reconstitution. Chem. A Eur. J. 12, 6071-6080. doi: 10. 1002/chem.200600089

Bontempo, D., and Maynard, H. D. (2005). Streptavidin as a macroinitiator for polymerization: in situ protein-polymer conjugate formation. J. Am. Chem. Soc. 127, 6508-6509. doi: 10.1021/ja042230

Bosio, V. E., Islan, G. A., Martínez, Y. N., Durán, N., and Castro, G. R. (2016). Nanodevices for the immobilization of therapeutic enzymes. Crit. Rev. Biotechnol. 36, 447-464. doi: 10.3109/07388551.2014.990414

Boyer, C., Bulmus, V., and Davis, T. P. (2009). Efficient usage of thiocarbonates for both the production and the biofunctionalization of polymers. Macromol. Rapid Commun. 30, 493-497. doi: 10.1002/marc.200800708

Boyer, C., Bulmus, V., Liu, J., Davis, T. P., Stenzel, M. H., and BarnerKowollik, C. (2007). Well-defined protein-polymer conjugates via in situ RAFT polymerization. J. Am. Chem. Soc. 129, 7145-7154. doi: 10.1021/ja070956a

Breger, J. C., Ancona, M. G., Walper, S. A., Oh, E., Susumu, K., Stewart, M. H., et al. (2015). Phosphotriesterase kinetic efficiency. ACS Nano 9, 8491-8503. doi: 10.1021/acsnano.5b03459

Calleri, E., Temporini, C., Gasparrini, F., Simone, P., Villani, C., Ciogli, A., et al. (2011). Immobilized trypsin on epoxy organic monoliths with modulated hydrophilicity: novel bioreactors useful for protein analysis by liquid chromatography coupled to tandem mass spectrometry. J. Chromatogr. A 1218, 8937-8945. doi: 10.1016/j.chroma.2011.05.059

Canalle, L. A., Löwik, D. W. P. M., and Van Hest, J. C. M. (2010). Polypeptidepolymer bioconjugates. Chem. Soc. Rev. 39, 329-353. doi: 10.1039/b807871h

Care, A., Petroll, K., Gibson, E. S. Y., Bergquist, P. L., and Sunna, A. (2017). Solidbinding peptides for immobilisation of thermostable enzymes to hydrolyse biomass polysaccharides. Biotechnol. Biofuels 10:29. doi: 10.1186/s13068-0170715-2

Carmali, S., Murata, H., Cummings, C., Matyjaszewski, K., and Russell, A. J. (2017). Polymer-based protein engineering: synthesis and characterization of armored, high graft density polymer-protein conjugates. Methods Enzymol. 590, 347-380. doi: 10.1016/bs.mie.2016.12.005

Caruso, F., Trau, D., Möhwald, H., and Renneberg, R. (2000). Enzyme encapsulation in layer-by-layer engineered polymer multilayer capsules. Langmuir 16, 1485-1488. doi: 10.1021/la991161n

Çetin, M. Z., and Camurlu, P. (2018). An amperometric glucose biosensor based on PEDOT nanofibers. RSC Adv. 8, 19724-19731. doi: 10.1039/c8ra01385c

Chapman, R., and Stenzel, M. H. (2019). All wrapped up: stabilization of enzymes within single enzyme nanoparticles. J. Am. Chem. Soc. 141, 2754-2769. doi: $10.1021 /$ jacs. 8 b10338

Chauhan, N., Chawla, S., Pundir, C. S., and Jain, U. (2017). An electrochemical sensor for detection of neurotransmitter-acetylcholine using metal nanoparticles, 2D material and conducting polymer modified electrode. Biosens. Bioelectron. 89, 377-383. doi: 10.1016/j.bios.2016.06.047

Chen, B., Pernodet, N., Rafailovich, M. H., Bakhtina, A., and Gross, R. A. (2008). Protein immobilization on epoxy-activated thin polymer films: effect of surface wettability and enzyme loading. Langmuir 24, 13457-13464. doi: 10.1021/ la8019952 
Chen, H., Liu, L. H., Wang, L. S., Ching, C. B., Yu, H. W., and Yang, Y. Y. (2008). Thermally responsive reversed micelles for immobilization of enzymes. $A d v$. Funct. Mater. 18, 95-102. doi: 10.1002/adfm.200600452

Chen, G., Abdeen, A. A., Wang, Y., Shahi, P. K., Robertson, S., Xie, R., et al. (2019). A biodegradable nanocapsule delivers a Cas 9 ribonucleoprotein complex for in vivo genome editing. Nat. Nanotechnol. 14, 974-980. doi: 10.1038/s41565019-0539-2

Chen, Q., Schönherr, H., and Vancso, G. J. (2009). Block-copolymer vesicles as nanoreactors for enzymatic reactions. Small 5, 1436-1445. doi: 10.1002/smll. 200801455

Chen, T. T., Yi, J. T., Zhao, Y. Y., and Chu, X. (2018). Biomineralized metal-organic framework nanoparticles enable intracellular delivery and endo-lysosomal release of native active proteins. J. Am. Chem. Soc. 140, 9912-9920. doi: 10.1021/ jacs.8b04457

Chen, Y., Lykourinou, V., Vetromile, C., Hoang, T., Ming, L. J., Larsen, R. W., et al. (2012). How can proteins enter the interior of a MOF? investigation of cytochrome $\mathrm{c}$ translocation into a MOF consisting of mesoporous cages with microporous windows. J. Am. Chem. Soc. 134, 13188-13191. doi: 10.1021/ ja305144x

Cheng, H., Zhao, Y. L., Luo, X. J., Xu, D. S., Cao, X., Xu, J. H., et al. (2018). Cross-linked enzyme-polymer conjugates with excellent stability and detergent-enhanced activity for efficient organophosphate degradation. Bioresour. Bioprocess. 5:49. doi: 10.1186/s40643-018-0236-2

Cheng, H., Zhu, J. Y., Li, S. Y., Zeng, J. Y., Lei, Q., Chen, K. W., et al. (2016). An $\mathrm{O}_{2}$ self-sufficient biomimetic nanoplatform for highly specific and efficient photodynamic therapy. Adv. Funct. Mater. 26, 7847-7860. doi: 10.1002/adfm. 201603212

Cheng, M., Wang, R., Zhang, B., Mao, Z., and Chen, Z. (2019). Rapid proteolytic digestion and peptide separation using monolithic enzyme microreactor coupled with capillary electrophoresis. J. Pharm. Biomed. Anal. 165, 129-134. doi: 10.1016/j.jpba.2018.11.063

Chiang, C. W., Liu, X., Sun, J., Guo, J., Tao, L., and Gao, W. (2020). Polymerizationinduced coassembly of enzyme-polymer conjugates into comicelles with tunable and enhanced cascade activity. Nano Lett. 20, 1383-1387. doi: 10.1021/ acs.nanolett.9b04959

Christwardana, M., Chung, Y., and Kwon, Y. (2017). Co-immobilization of glucose oxidase and catalase for enhancing the performance of a membraneless glucose biofuel cell operated under physiological conditions. Nanoscale 9, 1993-2002. doi: 10.1039/c6nr09103b

Chung, Y., Ahn, Y., Christwardana, M., Kim, H., and Kwon, Y. (2016). Development of a glucose oxidase-based biocatalyst adopting both physical entrapment and crosslinking, and its use in biofuel cells. Nanoscale 8, 92019210. doi: 10.1039/C6NR00902F

Cleeton, C., Keirouz, A., Chen, X., and Radacsi, N. (2019). Electrospun nanofibers for drug delivery and biosensing. ACS Biomater. Sci. Eng. 5, 4183-4205. doi: 10.1021/acsbiomaterials.9b00853

Cobo, I., Li, M., Sumerlin, B. S., and Perrier, S. (2015). Smart hybrid materials by conjugation of responsive polymers to biomacromolecules. Nat. Mater. 14, 143-149. doi: 10.1038/nmat4106

Coscolín, C., Beloqui, A., Martínez-Martínez, M., Bargiela, R., Santiago, G., Blanco, R. M., et al. (2018). Controlled manipulation of enzyme specificity through immobilization-induced flexibility constraints. Appl. Catal. A Gen. 565, 59-67. doi: 10.1016/j.apcata.2018.08.003

Coulet, P. R., Carlsson, J., and Porath, J. (1981). Immobilization of enzymes on metal-chelate regenerable carriers. Biotechnol. Bioeng. 23, 663-668. doi: 10. 1002/bit.260230316

Cuomo, F., Ceglie, A., De Leonardis, A., and Lopez, F. (2019). Polymer capsules for enzymatic catalysis in confined environments. Catalysts 9, 1-18. doi: 10.3390/ catal9010001

Dai, G., Hu, J., Zhao, X., and Wang, P. (2017). A colorimetric paper sensor for lactate assay using a cellulose-Binding recombinant enzyme. Sens. Actuat. B Chem. 238, 138-144. doi: 10.1016/j.snb.2016.07.008

Daunert, S., Bachas, L. G., Schauer-Vukasinovic, V., Gregory, K. J., Schrift, G., and Deo, S. (2007). Calmodulin-mediated reversible immobilization of enzymes. Colloids Surf. B Biointerf. 58, 20-27. doi: 10.1016/j.colsurfb.2006.10.020

David, M., Barsan, M. M., Brett, C. M. A., and Florescu, M. (2018). Improved glucose label-free biosensor with layer-by-layer architecture and conducting polymer poly(3,4-ethylenedioxythiophene). Sens. Actuat. B Chem. 255, 32273234. doi: 10.1016/j.snb.2017.09.149

De Simone, A., Naldi, M., Bartolini, M., Davani, L., and Andrisano, V. (2019). Immobilized enzyme reactors: an overview of applications in drug discovery from 2008 to 2018. Chromatographia 82, 425-441. doi: 10.1007/s10337-0183663-5

Dedisch, S., Wiens, A., Davari, M. D., Soder, D., Rodriguez-Emmenegger, C., Jakob, F., et al. (2020). Matter- tag?: a universal immobilization platform for enzymes on polymers, metals, and silicon-based materials. Biotechnol. Bioeng. 117, 49-61. doi: 10.1002/bit.27181

Delaittre, G., Reynhout, I. C., Cornelissen, J. J. L. M., and Nolte, R. J. M. (2009). Cascade reactions in an all-enzyme nanoreactor. Chem. A Eur. J. 15, 1260012603. doi: 10.1002/chem.200902063

Dinçer, A., and Telefoncu, A. (2007). Improving the stability of cellulase by immobilization on modified polyvinyl alcohol coated chitosan beads. J. Mol. Catal. B Enzym. 45, 10-14. doi: 10.1016/j.molcatb.2006.10.005

Dong, S., Peng, L., Wei, W., and Huang, T. (2018). Three MOF-templated carbon nanocomposites for potential platforms of enzyme immobilization with improved electrochemical performance. ACS Appl. Mater. Interf. 10, 1466514672. doi: 10.1021/acsami.8b00702

Duan, R., Sun, L., Yang, H. Y., Ma, Y. R., Deng, X. Y., Peng, C., et al. (2020). Preparation of phenyl-boronic acid polymeric monolith by initiatorfree ring-opening polymerization for microextraction of sulfonamides prior to their determination by ultra-performance liquid chromatography-tandem mass spectrometry. J. Chromatogr. A 1609:460510. doi: 10.1016/j.chroma.2019. 460510

Fan, P. R., Zhao, X., Wei, Z. H., Huang, Y. P., and Liu, Z. S. (2020). Robust immobilized enzyme reactor based on trimethylolpropane trimethacrylate organic monolithic matrix through "thiol-ene" click reaction. Eur. Polym. J. 124:109456. doi: 10.1016/j.eurpolymj.2019.109456

Fan, Y., Su, F., Li, K., Ke, C., and Yan, Y. (2017). Carbon nanotube filled with magnetic iron oxide and modified with polyamidoamine dendrimers for immobilizing lipase toward application in biodiesel production. Nat. Publ. Gr. 2017, 1-13. doi: 10.1038/srep45643

Fang, Y., Zhang, A., Li, S., Sproviero, M., and Xu, M. Q. (2019). Enzyme immobilization for solid-phase catalysis. Catalysts 9, 12-15. doi: 10.3390/ catal9090732

Farrugia, T., Perriman, A. W., Sharma, K. P., and Mann, S. (2017). Multi-enzyme cascade reactions using protein-polymer surfactant self-standing films. Chem. Commun. 53, 2094-2097. doi: 10.1039/c6cc09809f

Feng, Q., Tang, B., Wei, Q., Hou, D., Bi, S., and Wei, A. (2012). Preparation of a $\mathrm{Cu}(\mathrm{II})-\mathrm{PVA} / \mathrm{PA} 6$ composite nanofibrous membrane for enzyme immobilization. Int. J. Mol. Sci. 13, 12734-12746. doi: 10.3390/ijms131012734

Feng, Q., Wang, Q., Tang, B., Wei, A., Wang, X., Wei, Q., et al. (2013). Immobilization of catalases on amidoxime polyacrylonitrile nanofibrous membranes. Polym. Int. 62, 251-256. doi: 10.1002/pi.4293

Feng, Q., Zhao, Y., Wei, A., Li, C., Wei, Q., and Fong, H. (2014). Immobilization of catalase on electrospun PVA/PA6-Cu(II) nanofibrous membrane for the development of efficient and reusable enzyme membrane reactor. Environ. Sci. Technol. 48, 10390-10397. doi: 10.1021/es501845u

Fenoy, G. E., Marmisollé, W. A., Azzaroni, O., and Knoll, W. (2020). Acetylcholine biosensor based on the electrochemical functionalization of graphene fieldeffect transistors. Biosens. Bioelectron. 148:111796. doi: 10.1016/j.bios.2019. 111796

Gaitzsch, J., Huang, X., and Voit, B. (2016). Engineering functional polymer capsules toward smart nanoreactors. Chem. Rev. 116, 1053-1093. doi: 10.1021/ acs.chemrev.5b00241

Gao, J., Wang, C., and Tan, H. (2017). Lanthanide/nucleotide coordination polymers: an excellent host platform for encapsulating enzymes and fluorescent nanoparticles to enhance ratiometric sensing. J. Mater. Chem. B 5, 7692-7700. doi: 10.1039/c7tb02049j

Gao, J., Zhao, B., Wang, M., Serrano, M. A. C., Zhuang, J., Ray, M., et al. (2018). Supramolecular assemblies for transporting proteins across an immiscible solvent interface. J. Am. Chem. Soc. 140, 2421-2425. doi: 10.1021/jacs.7b13245

Gao, S., Wang, Z., Ma, L., Liu, Y., Gao, J., and Jiang, Y. (2020). Mesoporous coreshell nanostructures bridging metal and biocatalyst for highly efficient cascade reactions. ACS Catal. 10, 1375-1380. doi: 10.1021/acscatal.9b04877 
Gauthier, M. A., and Klok, H. A. (2010). Polymer-protein conjugates: an enzymatic activity perspective. Polym. Chem. 1, 1352-1373. doi: 10.1039/c0py90001j

Ge, J., Lu, D., Wang, J., and Liu, Z. (2009). Lipase nanogel catalyzed transesterification in anhydrous dimethyl sulfoxide. Biomacromolecules 10, 1612-1618. doi: 10.1021/bm900205r

Ge, J., Lu, D., Wang, J., Yan, M., Lu, Y., and Liu, Z. (2008). Molecular fundamentals of enzyme nanogels. J. Phys. Chem. B 112, 14319-14324. doi: 10.1021/ jp8053923

Geiser, L., Eeltink, S., Svec, F., and Fréchet, J. M. J. (2008). In-line system containing porous polymer monoliths for protein digestion with immobilized pepsin, peptide preconcentration and nano-liquid chromatography separation coupled to electrospray ionization mass spectroscopy. J. Chromatogr. A 1188, 88-96. doi: 10.1016/j.chroma.2008.02.075

Girelli, A. M., and Mattei, E. (2005). Application of immobilized enzyme reactor in on-line high performance liquid chromatography?: a review. Science 819, 3-16. doi: 10.1016/j.jchromb.2005.01.031

Gkaniatsou, E., Sicard, C., Ricoux, R., Mahy, J. P., Steunou, N., and Serre, C. (2017). Metal-organic frameworks: a novel host platform for enzymatic catalysis and detection. Mater. Horizons 4, 55-63. doi: 10.1039/c6mh00312e

Gu, Z., Yan, M., Hu, B., Joo, K. L., Biswas, A., Huang, Y., et al. (2009). Protein nanocapsule weaved with enzymatically degradable polymerie network. Nano Lett. 9, 4533-4538. doi: 10.1021/nl902935b

Guimarães, J., Giordano, R., Fernandez-Lafuente, R., and Tardioli, P. (2018). Evaluation of strategies to produce highly porous cross-linked aggregates of porcine pancreas lipase with magnetic properties. Molecules 23:2993. doi: 10. 3390/molecules 23112993

Guisán, J. M. (1988). Aldehyde-agarose gels as activated supports for immobilization-stabilization of enzymes. Enzyme Microb. Technol. 10, 375-382. doi: 10.1016/0141-0229(88)90018-X

Gupta, U., Agashe, H. B., Asthana, A., and Jain, N. K. (2006). Dendrimers: novel polymeric nanoarchitectures for solubility enhancement. Biomacromolecules 7 , 649-658. doi: 10.1021/bm050802s

Hamidi, M., Azadi, A., and Rafiei, P. (2008). Hydrogel nanoparticles in drug delivery. Adv. Drug Deliv. Rev. 60, 1638-1649. doi: 10.1016/j.addr.2008.08.002

Han, X., Xie, Y., Wu, Q., and Wu, S. (2019). The effect of monolith properties on the digestion performance of monolith-based immobilized enzyme microreactor. J. Chromatogr. Sci. 57, 116-121. doi: 10.1093/chromsci/bmy091

He, H., Han, H., Shi, H., Tian, Y., Sun, F., Song, Y., et al. (2016). Construction of thermophilic lipase-embedded metal-organic frameworks via biomimetic mineralization: a biocatalyst for ester hydrolysis and kinetic resolution. ACS Appl. Mater. Interf. 8, 24517-24524. doi: 10.1021/acsami.6b05538

He, J., Yang, H., Zhang, Y., Yu, J., Miao, L., Song, Y., et al. (2016). Smart nanocomposites of cu-hemin metal-organic frameworks for electrochemical glucose biosensing. Sci. Rep. 6:36637. doi: 10.1038/srep36637

He, L., Ni, Q., Mu, J., Fan, W., Liu, L., Wang, Z., et al. (2020). Solvent-assisted selfassembly of a metal-organic framework based biocatalyst for cascade reaction driven photodynamic therapy. J. Am. Chem. Soc. 142, 6822-6832. doi: 10.1021/ jacs.0c02497

Henke, P., Dolanskl, J., Kubát, P., and Mosinger, J. (2020). Multifunctional photosensitizing and biotinylated polystyrene nanofiber membranes/composites for binding of biologically active compounds. ACS Appl. Mater. Interf. 12, 18792-18802. doi: 10.1021/acsami.9b23104

Hermanson, G. T. (2008). Bioconjugate Techniques. Amsterdam: Elsevier.

Hiep Nguyen, H., and Kim, M. (2017). An overview of techniques in enzyme immobilization. Appl. Sci. Converg. Technol. 26, 157-163. doi: 10.5757/ASCT. 2017.26.6.157

Hola, K., Markova, Z., Zoppellaro, G., Tucek, J., and Zboril, R. (2015). Tailored functionalization of iron oxide nanoparticles for MRI, drug delivery, magnetic separation and immobilization of biosubstances. Biotechnol. Adv. 33, 11621176. doi: 10.1016/j.biotechadv.2015.02.003

Hu, C., Bai, Y., Hou, M., Wang, Y., Wang, L., Cao, X., et al. (2020). Defect-induced activity enhancement of enzyme-encapsulated metal-organic frameworks revealed in microfluidic gradient mixing synthesis. Sci. Adv. 6:eaax5785. doi: 10.1126/sciadv.aax 5785

Huang, A., and Olsen, B. D. (2016). Self-assembly of differently shaped proteinpolymer conjugates through modification of the bioconjugation site. Macromol. Rapid Commun. 37, 1268-1274. doi: 10.1002/marc.201500744
Jesionowski, T., Zdarta, J., and Krajewska, B. (2014). Enzyme immobilization by adsorption: a review. Adsorption 20, 801-821. doi: 10.1007/s10450-014-9623-y

Ji, X., Liu, J., Liu, L., and Zhao, H. (2016). Enzyme-polymer hybrid nanogels fabricated by thiol-disulfide exchange reaction. Coll. Surf. B Biointerf. 148, 41-48. doi: 10.1016/j.colsurfb.2016.08.043

Jiang, H., and Xu, F. J. (2013). Biomolecule-functionalized polymer brushes. Chem. Soc. Rev. 42, 3394-3426. doi: 10.1039/c2cs35453e

Jin, W., Xu, Y., and Yu, X. W. (2019). Preparation of lipase cross-linked enzyme aggregates in octyl-modified mesocellular foams. Int. J. Biol. Macromol. 130, 342-347. doi: 10.1016/j.ijbiomac.2019.02.154

Jivan, F., Yegappan, R., Pearce, H., Carrow, J. K., McShane, M., Gaharwar, A. K., et al. (2016). Sequential thiol-ene and tetrazine click reactions for the polymerization and functionalization of hydrogel microparticles. Biomacromolecules 17, 3516-3523. doi: 10.1021/acs.biomac.6b00990

Jun, S. H., Yang, J., Jeon, H., Kim, H. S., Pack, S. P., Jin, E., et al. (2020). Stabilized and immobilized carbonic anhydrase on electrospun nanofibers for enzymatic $\mathrm{CO}_{2}$ conversion and utilization in expedited microalgal growth. Environ. Sci. Technol. 54, 1223-1231. doi: 10.1021/acs.est.9b05284

Jung, S., and Kwon, I. (2016). Expansion of bioorthogonal chemistries towards site-specific polymer-protein conjugation. Polym. Chem. 7, 4584-4598. doi: 10.1039/c6py00856a

Karamitros, C. S., Yashchenok, A. M., Möhwald, H., Skirtach, A. G., and Konrad, M. (2013). Preserving catalytic activity and enhancing biochemical stability of the therapeutic enzyme asparaginase by biocompatible multilayered polyelectrolyte microcapsules. Biomacromolecules 14, 4398-4406. doi: 10.1021/ bm401341k

Keefe, A. J., and Jiang, S. (2012). Poly(zwitterionic)protein conjugates offer increased stability without sacrificing binding affinity or bioactivity. Nat. Chem. 4, 59-63. doi: $10.1038 /$ nchem. 1213

Keller, D., Beloqui, A., Martínez-Martínez, M., Ferrer, M., and Delaittre, G. (2017). Nitrilotriacetic amine-functionalized polymeric core-shell nanoparticles as enzyme immobilization supports. Biomacromolecules 18, 2777-2788. doi: 10. 1021/acs.biomac.7b00677

Keller, S., Teora, S. P., Hu, G. X., Nijemeisland, M., and Wilson, D. A. (2018). Highthroughput design of biocompatible enzyme-based hydrogel microparticles with autonomous movement. Angew. Chem. Int. Edn. 57, 9814-9817. doi: 10. 1002/anie.201805661

Kergoat, L., Piro, B., Simon, D. T., Pham, M. C., Noël, V., and Berggren, M. (2014). Detection of glutamate and acetylcholine with organic electrochemical transistors based on conducting polymer/platinum nanoparticle composites. Adv. Mater. 26, 5658-5664. doi: 10.1002/adma.201401608

Kim, K. T., Cornelissen, J. J. L. M., Nolte, R. J. M., and Van Hest, J. C. M. (2009). A polymersome nanoreactor with controllable permeability induced by stimuliresponsive block copolymers. Adv. Mater. 21, 2787-2791. doi: 10.1002/adma. 200900300

Kim, M., Gkikas, M., Huang, A., Kang, J. W., Suthiwangcharoen, N., Nagarajan, R., et al. (2014). Enhanced activity and stability of organophosphorus hydrolase via interaction with an amphiphilic polymer. Chem. Commun. 50, 5345-5348. doi: $10.1039 / \mathrm{c} 3 \mathrm{cc} 47675 \mathrm{~h}$

Klermund, L., Poschenrieder, S. T., and Castiglione, K. (2017). Biocatalysis in polymersomes: improving multienzyme cascades with incompatible reaction steps by compartmentalization. ACS Catal. 7, 3900-3904. doi: 10.1021/acscatal. $7 \mathrm{~b} 00776$

Knob, R., Sahore, V., Sonker, M., and Woolley, A. T. (2016). Advances in monoliths and related porous materials for microfluidics. Biomicrofluidics 10:032901. doi: $10.1063 / 1.4948507$

Ko, J. H., and Maynard, H. D. (2018). A guide to maximizing the therapeutic potential of protein-polymer conjugates by rational design. Chem. Soc. Rev. 47, 8998-9014. doi: 10.1039/c8cs00606g

Koenig, M., Bittrich, E., König, U., Rajeev, B. L., Müller, M., Eichhorn, K. J., et al. (2016). Adsorption of enzymes to stimuli-responsive polymer brushes: influence of brush conformation on adsorbed amount and biocatalytic activity. Coll. Surf. B Biointerf. 146, 737-745. doi: 10.1016/j.colsurfb.2016. 07.015

Kovaliov, M., Cheng, C., Cheng, B., and Averick, S. (2018). Grafting-from lipase: utilization of a common amino acid residue as a new grafting site. Polym. Chem. 9, 4651-4659. doi: 10.1039/c8py01026a 
Kowsari, M., Motallebi, M., and Zamani, M. (2014). Protein engineering of chit42 towards improvement of chitinase and antifungal activities. Curr. Microbiol. 68, 495-502. doi: 10.1007/s00284-013-0494-3

Krenkova, J., Lacher, N. A., and Svec, F. (2009). Highly effcient enzyme reactors containing trypsin and endoproteinase lysc immobilized on porous polymer monolith coupled to ms suitable for analysis of antibodies. Anal. Chem. 81, 2004-2012. doi: 10.1021/ac8026564

Krishna, O. D., and Kiick, K. L. (2010). Protein- and peptide-modified synthetic polymeric biomaterials. Biopolymers 94, 32-48. doi: 10.1002/bip.21333

Labus, K., Gancarz, I., and Bryjak, J. (2012). Immobilization of laccase and tyrosinase on untreated and plasma-treated cellulosic and polyamide membranes. Mater. Sci. Eng. C 32, 228-235. doi: 10.1016/j.msec.2011.10.023

Li, M., Qiao, S., Zheng, Y., Andaloussi, Y. H., Li, X., Zhang, Z., et al. (2020). Fabricating covalent organic framework capsules with commodious microenvironment for enzymes. J. Am. Chem. Soc. 142, 6675-6681. doi: 10. 1021/jacs.0c00285

Li, N., Zheng, W., Shen, Y., Qi, L., Li, Y., Qiao, J., et al. (2014). Preparation of a novel polymer monolith with functional polymer brushes by two-step atom-transfer radical polymerization for trypsin immobilization. J. Sep. Sci. 37, 3411-3417. doi: $10.1002 /$ jssc. 201400794

Li, S. F., Chen, J. P., and Wu, W. T. (2007). Electrospun polyacrylonitrile nanofibrous membranes for lipase immobilization. J. Mol. Catal. B Enzym. 47, 117-124. doi: 10.1016/j.molcatb.2007.04.010

Li, S. Y., Cheng, H., Xie, B. R., Qiu, W. X., Zeng, J. Y., Li, C. X., et al. (2017). Cancer cell membrane camouflaged cascade bioreactor for cancer targeted starvation and photodynamic therapy. ACS Nano 11, 7006-7018. doi: 10.1021/acsnano. $7 \mathrm{~b} 02533$

Li, Y., Dennis Tolley, H., and Lee, M. L. (2010). Monoliths from poly(ethylene glycol) diacrylate and dimethacrylate for capillary hydrophobic interaction chromatography of proteins. J. Chromatogr. A 1217, 4934-4945. doi: 10.1016/j. chroma.2010.05.048

Liang, K., Coghlan, C. J., Bell, S. G., Doonan, C., and Falcaro, P. (2016). Enzyme encapsulation in zeolitic imidazolate frameworks: a comparison between controlled co-precipitation and biomimetic mineralisation. Chem. Commun. 52, 473-476. doi: 10.1039/c5cc07577g

Liang, S., Wu, X.-L., Xiong, J., Zong, M.-H., and Lou, W.-Y. (2020). Metal-organic frameworks as novel matrices for efficient enzyme immobilization: an update review. Coord. Chem. Rev. 406:213149. doi: 10.1016/j.ccr.2019.213149

Liang, W., Xu, H., Carraro, F., Maddigan, N. K., Li, Q., Bell, S. G., et al. (2019). Enhanced activity of enzymes encapsulated in hydrophilic metal-organic frameworks. J. Am. Chem. Soc. 141, 2348-2355. doi: 10.1021/jacs.8b10302

Liang, Y., Tao, D., Ma, J., Sun, L., Liang, Z., Zhang, L., et al. (2011). Hydrophilic monolith based immobilized enzyme reactors in capillary and on microchip for high-throughput proteomic analysis. J. Chromatogr. A 1218, 2898-2905. doi: 10.1016/j.chroma.2011.02.073

Lin, Q., Tang, M., and Ke, C. (2020). Thermo-responsive 3D-printed polyrotaxane monolith. Polym. Chem. 11, 304-308. doi: 10.1039/c9py01510h

Liu, C., Wan, T., Wang, H., Zhang, S., Ping, Y., and Cheng, Y. (2019). A boronic acid-rich dendrimer with robust and unprecedented efficiency for cytosolic protein delivery and CRISPR-Cas9 gene editing. Sci. Adv. 5:eaaw8922. doi: 10.1126/sciadv.aaw8922

Liu, Q., Xun, G., and Feng, Y. (2019). The state-of-the-art strategies of protein engineering for enzyme stabilization. Biotechnol. Adv. 37, 530-537. doi: 10. 1016/j.biotechadv.2018.10.011

Liu, Y., Turner, A. P. F., Zhao, M., and Mak, W. C. (2018). Processable enzymehybrid conductive polymer composites for electrochemical biosensing. Biosens. Bioelectron. 100, 374-381. doi: 10.1016/j.bios.2017.09.021

Logan, T. C., Clark, D. S., Stachowiak, T. B., Svec, F., and Fréchet, J. M. J. (2007). Photopatterning enzymes on polymer monoliths in microfluidic devices for steady-state kinetic analysis and spatially separated multi-enzyme reactions. Anal. Chem. 79, 6592-6598. doi: 10.1021/ac070705k

López-Gallego, F., Acebrón, I., Mancheño, J. M., Raja, S., Lillo, M. P., and Guisán Seijas, J. M. (2012). Directed, strong, and reversible immobilization of proteins tagged with a $\beta$-trefoil lectin domain: a simple method to immobilize biomolecules on plain agarose matrixes. Bioconjug. Chem. 23, 565-573. doi: $10.1021 /$ bc2006237

López-Gallego, F., Betancor, L., Hidalgo, A., Alonso, N., Fernández-Lafuente, R., and Guisán, J. M. (2005). Co-aggregation of enzymes and polyethyleneimine: a simple method to prepare stable and immobilized derivatives of glutaryl acylase. Biomacromolecules 6, 1839-1842. doi: 10.1021/bm050088e

Lu, X., Wang, X., Wu, L., Wu, L., Dhanjai, J., Fu, L., et al. (2016). Response characteristics of bisphenols on a metal-organic framework-based tyrosinase nanosensor. ACS Appl. Mater. Interfaces 8, 16533-16539. doi: 10.1021/acsami. $6 \mathrm{~b} 05008$

Luo, J., Ma, L., Svec, F., Tan, T., and Lv, Y. (2019). Reversible two-enzyme coimmobilization on ph-responsive imprinted monolith for glucose detection. Biotechnol. J. 14:1900028. doi: 10.1002/biot.201900028

Lv, Y., Lin, Z., Tan, T., and Svec, F. (2014). Preparation of reusable bioreactors using reversible immobilization of enzyme on monolithic porous polymer support with attached gold nanoparticles. Biotechnol. Bioeng. 111, 50-58. doi: 10.1002/ bit. 25005

Lyu, F., Zhang, Y., Zare, R. N., Ge, J., and Liu, Z. (2014). One-pot synthesis of protein-embedded metal-organic frameworks with enhanced biological activities. Nano Lett. 14, 5761-5765. doi: 10.1021/nl5026419

Ma, S., Li, Y., Ma, C., Wang, Y., Ou, J., and Ye, M. (2019). Challenges and advances in the fabrication of monolithic bioseparation materials and their applications in proteomics research. Adv. Mater. 31, 1-27. doi: 10.1002/adma.201902023

Maiti, S., Ghosh, M., and Das, P. K. (2011). Gold nanorod in reverse micelles: a fitting fusion to catapult lipase activity. Chem. Commun. 47:9864. doi: 10.1039/ clcc12940f

Marcus, R. A., and Sutin, N. (1985). Electron transfers in chemistry and biology. Biochim. Biophys. Acta - Rev. Bioenerg. 811, 265-322. doi: 10.1016/03044173(85)90014-X

Marquitan, M., Mark, M. D., Ernst, A., Muhs, A., Herlitze, S., Ruff, A., et al. (2020). Glutamate detection at the cellular level by means of polymer/enzyme multilayer modified carbon nanoelectrodes. J. Mater. Chem. B. 8, 3631-3639. doi: 10.1039/С9TB02461A

Masini, J. C., and Svec, F. (2017). Porous monoliths for on-line sample preparation: a review. Anal. Chim. Acta 964, 24-44. doi: 10.1016/j.aca.2017.02.002

Mateo, C., Palomo, J. M., Fernandez-Lorente, G., Guisan, J. M., and FernandezLafuente, R. (2007). Improvement of enzyme activity, stability and selectivity via immobilization techniques. Enzyme Microb. Technol. 40, 1451-1463. doi: 10.1016/j.enzmictec.2007.01.018

Mateo, C., Palomo, J. M., van Langen, L. M., van Rantwijk, F., and Sheldon, R. A. (2004). A new, mild cross-linking methodology to prepare cross-linked enzyme aggregates. Biotechnol. Bioeng. 86, 273-276. doi: 10.1002/bit.20033

Matoori, S., and Leroux, J.-C. (2020). Twenty-five years of polymersomes: lost in translation? Mater. Horizons. 7, 1297-1309. doi: 10.1039/C9MH01669D

Meller, K., Pomastowski, P., Szumski, M., and Buszewski, B. (2017). Preparation of an improved hydrophilic monolith to make trypsin-immobilized microreactors. J. Chromatogr. B Anal. Technol. Biomed. Life Sci. 1043, 128-137. doi: 10.1016/j.jchromb.2016.08.032

Messina, M. S., Messina, K. M. M., Bhattacharya, A., Montgomery, H. R., and Maynard, H. D. (2020). Preparation of biomolecule-polymer conjugates by grafting-from using ATRP. RAFT, or ROMP. Prog. Polym. Sci. 100:101186. doi: 10.1016/j.progpolymsci.2019.101186

Morgenstern, J., Gil Alvaradejo, G., Bluthardt, N., Beloqui, A., Delaittre, G., and Hubbuch, J. (2018). Impact of polymer bioconjugation on protein stability and activity investigated with discrete conjugates: alternatives to PEGylation. Biomacromolecules 19, 4250-4262. doi: 10.1021/acs.biomac.8b01020

Morshed, M. N., Behary, N., Bouazizi, N., Guan, J., Chen, G., and Nierstrasz, V. (2019). Surface modification of polyester fabric using plasma-dendrimer for robust immobilization of glucose oxidase enzyme. Sci. Rep. 9:15730. doi: 10.1038/s41598-019-52087-8

Moyano, F., Falcone, R. F., Mejuto, J. C., Silber, J. J., and Correa, N. M. (2010). Cationic reverse micelles create water with super hydrogen-bonddonor capacity for enzymatic catalysis: hydrolysis of 2-naphthyl acetate by $\alpha$-Chymotrypsin. Chem. A Eur. J. 16, 8887-8893. doi: 10.1002/chem.2010 00437

Nadar, S. S., Muley, A. B., Ladole, M. R., and Joshi, P. U. (2016). Macromolecular cross-linked enzyme aggregates (M-CLEAs) of $\alpha$-amylase. Int. J. Biol. Macromol. 84, 69-78. doi: 10.1016/j.ijbiomac.2015.11.082

Naldi, M., Èernigoj, U., Štrancar, A., and Bartolini, M. (2017). Towards automation in protein digestion: development of a monolithic trypsin immobilized reactor for highly efficient on-line digestion and analysis. Talanta 167, 143-157. doi: 10.1016/j.talanta.2017.02.016 
Nelson, J. M., and Griffin, E. G. (1916). Adsorption of invertase. J. Am. Chem. Soc. 38, 1109-1115. doi: 10.1021/ja02262a018

Ngo, T. P. N., Zhang, W., Wang, W., and Li, Z. (2012). Reversible clustering of magnetic nanobiocatalysts for high-performance biocatalysis and easy catalyst recycling. Chem. Commun. 48, 4585-4587. doi: 10.1039/c2cc30953j

Nicoli, R., Bartolini, M., Rudaz, S., Andrisano, V., and Veuthey, J. L. (2008). Development of immobilized enzyme reactors based on human recombinant cytochrome P450 enzymes for phase I drug metabolism studies. J. Chromatogr. A 1206, 2-10. doi: 10.1016/j.chroma.2008.05.080

Nien, P.-C., Tung, T.-S., and Ho, K.-C. (2006). Amperometric glucose biosensor based on entrapment of glucose oxidase in a Poly(3,4-ethylenedioxythiophene) film. Electroanalysis 18, 1408-1415. doi: 10.1002/elan.200603552

Pachioni-Vasconcelos, J. D. A., Lopes, A. M., Apolinário, A. C., Valenzuela-Oses, J. K., Costa, J. S. R., Nascimento, L. D. O., et al. (2016). Nanostructures for protein drug delivery. Biomater. Sci. 4, 205-218. doi: 10.1039/c5bm00360a

Palomo, J. M., Muoz, G., Fernández-Lorente, G., Mateo, C., Fernández-Lafuente, R., and Guisán, J. M. (2002). Interfacial adsorption of lipases on very hydrophobic support (octadecyl-Sepabeads): Immobilization, hyperactivation and stabilization of the open form of lipases. J. Mol. Catal. B Enzym. 19, 279-286. doi: 10.1016/S1381-1177(02)00178-9

Parakhonskiy, B. V., Yashchenok, A. M., Konrad, M., and Skirtach, A. G. (2014). Colloidal micro- and nano-particles as templates for polyelectrolyte multilayer capsules. Adv. Coll. Interf. Sci. 207, 253-264. doi: 10.1016/j.cis.2014.01.022

Parker, E. K., Nielsen, A. V., Beauchamp, M. J., Almughamsi, H. M., Nielsen, J. B., Sonker, M., et al. (2019). 3D printed microfluidic devices with immunoaffinity monoliths for extraction of preterm birth biomarkers. Anal. Bioanal. Chem. 411, 5405-5413. doi: 10.1007/s00216-018-1440-9

Peterson, D. S., Rohr, T., Svec, F., and Fréchet, J. M. J. (2002). Enzymatic microreactor-on-a-chip: protein mapping using trypsin immobilized on porous polymer monoliths molded in channels of microfluidic devices. Anal. Chem. 74, 4081-4088. doi: 10.1021/ac020180q

Peterson, D. S., Rohr, T., Svec, F., and Fréchet, J. M. J. (2003). Dual-function microanalytical device by in situ photolithographic grafting of porous polymer monolith: integrating solid-phase extraction and enzymatic digestion for peptide mass mapping. Anal. Chem. 75, 5328-5335. doi: 10.1021/ac034108j

Piro, B., Dang, L. A., Pham, M. C., Fabiano, S., and Tran-Minh, C. (2001). A glucose biosensor based on modified-enzyme incorporated within electropolymerised poly(3,4-ethylenedioxythiophene) (PEDT) films. J. Electroanal. Chem. 512, 101-109. doi: 10.1016/S0022-0728(01)00595-2

Pitzalis, F., Carucci, C., Naseri, M., Fotouhi, L., Magner, E., and Salis, A. (2018). Lipase encapsulation onto ZIF-8: a comparison between biocatalysts obtained at low and high zinc/2-methylimidazole molar ratio in aqueous medium. Chemcatchem 10, 1578-1585. doi: 10.1002/cctc.201701984

Qian, D., Nakamura, C., Zorin, N., and Miyake, J. (2002). Hydrogenasepoly(viologen) complex monolayers and electrochemical properties in langmuir-blodgett films. Coll. Surf. A Physicochem. Eng. Asp. 198-200, 663-669. doi: 10.1016/S0927-7757(01)00974-8

Rahman, M. A., Kwon, N. H., Won, M. S., Choe, E. S., and Shim, Y. B. (2005). Functionalized conducting polymer as an enzyme-immobilizing substrate: an amperometric glutamate microbiosensor for in vivo measurements. Anal. Chem. 77, 4854-4860. doi: 10.1021/ac050558v

Rehman, S., Bhatti, H. N., Bilal, M., and Asgher, M. (2016). Cross-linked enzyme aggregates (CLEAs) of Pencilluim notatum lipase enzyme with improved activity, stability and reusability characteristics. Int. J. Biol. Macromol. 91, 1161-1169. doi: 10.1016/j.ijbiomac.2016.06.081

Ren, L., Lv, J., Wang, H., and Cheng, Y. (2020). A coordinative dendrimer achieves excellent efficiency in cytosolic protein and peptide delivery. Angew. Chem. Int. Edn. 59, 4711-4719. doi: 10.1002/anie.201914970

Rodrigues, R. C., Ortiz, C., Berenguer-Murcia, A., Torres, R., and FernándezLafuente, R. (2013). Modifying enzyme activity and selectivity by immobilization. Chem. Soc. Rev. 42, 6290-6307. doi: 10.1039/c2cs35231a

Rodriguez-Abetxuko, A., Morant-Minana, M. C., Knez, M., and Beloqui, A. (2019a). Carrierless immobilization route for highly robust metal-organic hybrid enzymes. ACS Omega 4, 5172-5179. doi: 10.1021/acsomega.8b03559

Rodriguez-Abetxuko, A., Sánchez-deAlcázar, D., Cortajarena, A. L., and Beloqui, A. (2019b). A versatile approach for the assembly of highly tunable biocatalytic thin films. Adv. Mater. Interf. 6, 1-9. doi: 10.1002/admi.201900598

Rodriguez-Abetxuko, A., Morant-Miñana, M. C., López-Gallego, F., Yate, L., Seifert, A., Knez, M., et al. (2018). Imidazole-grafted nanogels for the fabrication of organic-inorganic protein hybrids. Adv. Funct. Mater. 28:1803115. doi: 10. 1002/adfm.201803115

Rodriguez-Abetxuko, A., Muñumer, P., Okuda, M., Calvo, J., Knez, M., and Beloqui, A. (2020). Nanoconfined (Bio)catalysts as efficient glucose-responsive nanoreactors. Adv. Funct. Mater. 2002990. doi: 10.1002/adfm.202002990

Sahutoglu, A. S., and Akgul, C. (2015). Immobilisation of Aspergillus oryzae $\alpha-$ amylase and Aspergillus niger glucoamylase enzymes as cross-linked enzyme aggregates. Chem. Pap. 69, 433-439. doi: 10.1515/chempap-2015-0031

Sakai, S., Antoku, K., Yamaguchi, T., and Kawakami, K. (2008). Development of electrospun poly(vinyl alcohol) fibers immobilizing lipase highly activated by alkyl-silicate for flow-through reactors. J. Memb. Sci. 325, 454-459. doi: 10.1016/j.memsci.2008.08.008

Sakr, O. S., and Borchard, G. (2013). Encapsulation of enzymes in layer-bylayer (LbL) structures: latest advances and applications. Biomacromolecules 14, 2117-2135. doi: 10.1021/bm400198p

Sánchez-deAlcázar, D., Velasco-Lozano, S., Zeballos, N., López-Gallego, F., and Cortajarena, A. L. (2019). Biocatalytic protein-based materials for integration into energy devices. Chembiochem 20, 1977-1985. doi: 10.1002/cbic.201900047

Sassolas, A., Blum, L. J., and Leca-bouvier, B. D. (2012). Immobilization strategies to develop enzymatic biosensors. Biotechnol. Adv. 30, 489-511. doi: 10.1016/j. biotechadv.2011.09.003

Scodeller, P., Williams, F. J., and Calvo, E. J. (2014). XPS analysis of enzyme and mediator at the surface of a layer-by-layer self-assembled wired enzyme electrode. Anal. Chem. 86, 12180-12184. doi: 10.1021/ac503147c

Serwa, R., Majkut, P., Horstmann, B., Swiecicki, J. M., Gerrits, M., Krause, E., et al. (2010). Site-specific PEGylation of proteins by a staudinger-phosphite reaction. Chem. Sci. 1, 596-602. doi: 10.1039/c0sc00324g

Sharma, K. P., Collins, A. M., Perriman, A. W., and Mann, S. (2013). Enzymatically active self-standing protein-polymer surfactant films prepared by hierarchical self-assembly. Adv. Mater. 25, 2005-2010. doi: 10.1002/adma.201204161

Shen, H., Song, J., Zhou, Z., Li, M., Zhang, R., Su, P., et al. (2019). DNAdirected immobilized enzymes on recoverable magnetic nanoparticles shielded in nucleotide coordinated polymers. Ind. Eng. Chem. Res. 58, 8585-8596. doi: 10.1021/acs.iecr.9b01341

Sintra, T. E., Ventura, S. P. M., and Coutinho, J. A. P. (2014). Superactivity induced by micellar systems as the key for boosting the yield of enzymatic reactions. J. Mol. Catal. B Enzym. 107, 140-151. doi: 10.1016/j.molcatb.2014. 06.001

Sproß, J., and Sinz, A. (2010). A Capillary monolithic trypsin reactor for efficient protein digestion in online and offline coupling to ESI and MALDI mass spectrometry. Anal. Chem. 82, 1434-1443. doi: 10.1021/ac9025362

Sueyoshi, D., Anraku, Y., Komatsu, T., Urano, Y., and Kataoka, K. (2017). Enzymeloaded polyion complex vesicles as in vivo nanoreactors working sustainably under the blood circulation: characterization and functional evaluation. Biomacromolecules 18, 1189-1196. doi: 10.1021/acs.biomac.6b01870

Šulek, F., Fernández, D. P., Knez, Ž, Habulin, M., and Sheldon, R. A. (2011). Immobilization of horseradish peroxidase as crosslinked enzyme aggregates (CLEAs). Process Biochem. 46, 765-769. doi: 10.1016/j.procbio.2010.12.001

Sun, C., Cheng, Y., Pan, Y., Yang, J., Wang, X., and Xia, F. (2020). Efficient polymerase chain reaction assisted by metal-organic frameworks. Chem. Sci. 11, 797-802. doi: $10.1039 / \mathrm{c} 9 \mathrm{sc} 03202 \mathrm{a}$

Sun, X. L., Yang, L. C., and Chaikof, E. L. (2008). Chemoselective immobilization of biomolecules through aqueous Diels-Alder and PEG chemistry. Tetrahedron Lett. 49, 2510-2513. doi: 10.1016/j.tetlet.2008.02.111

Sureka, H. V., Obermeyer, A. C., Flores, R. J., and Olsen, B. D. (2019). Catalytic biosensors from complex coacervate core micelle (C3M) thin films. ACS Appl. Mater. Interf. 11, 32354-32365. doi: 10.1021/acsami.9b08478

Suthiwangcharoen, N., and Nagarajan, R. (2014). Enhancing enzyme stability by construction of polymer-enzyme conjugate micelles for decontamination of organophosphate agents. Biomacromolecules 15, 1142-1152. doi: 10.1021/ bm401531d

Tao, L., Mantovani, G., Lecolley, F., and Haddleton, D. M. (2004). $\alpha$-aldehyde terminally functional methacrylic polymers from living radical polymerization: application in protein conjugation "pegylation.". J. Am. Chem. Soc. 126, 13220-13221. doi: 10.1021/ja0456454

Teepoo, S., Dawan, P., and Barnthip, N. (2017). Electrospun chitosan-gelatin biopolymer composite nanofibers for horseradish peroxidase immobilization in a hydrogen peroxide biosensor. Biosensors 7:47. doi: 10.3390/bios704 0047 
Torabizadeh, H., Tavakoli, M., and Safari, M. (2014). Immobilization of thermostable $\alpha$-amylase from Bacillus licheniformis by cross-linked enzyme aggregates method using calcium and sodium ions as additives. J. Mol. Catal. B Enzym. 108, 13-20. doi: 10.1016/j.molcatb.2014.06.005

Turecek, P. L., Bossard, M. J., Schoetens, F., and Ivens, I. A. (2016). PEGylation of biopharmaceuticals: a review of chemistry and nonclinical safety information of approved drugs. J. Pharm. Sci. 105, 460-475. doi: 10.1016/j.xphs.2015.11.015

Vahidi, A. K., Wang, Z., Wong, W. S. Y., and Li, Z. (2016). Immobilization of: $\mathrm{O}$-acetylserine sulfhydrylase as a highly active and recyclable nanobiocatalyst: efficient synthesis of $\beta$-pyrazol-1-yl-1-alanine. Catal. Sci. Technol. 6, 6286-6293. doi: $10.1039 /$ c6cy00755d

Varlas, S., Foster, J. C., Georgiou, P. G., Keogh, R., Husband, J. T., Williams, D. S., et al. (2019). Tuning the membrane permeability of polymersome nanoreactors developed by aqueous emulsion polymerization-induced selfassembly. Nanoscale 11, 12643-12654. doi: 10.1039/c9nr02507c

Vázquez, E., Aguilar, A. E., Moggio, I., Arias, E., Romero, J., Barrientos, H., et al. (2007). Immobilization of the enzyme $\beta$-lactamase by self-assembly on thin films of a poly(phenyleneethynylene) sequenced with flexible segments containing sulfur atoms. Mater. Sci. Eng. C 27, 787-793. doi: 10.1016/j.msec. 2006.08.022

Velasco-Lozano, S., López-Gallego, F., Mateos-Díaz, J. C., and Favela-Torres, E. (2016). Cross-linked enzyme aggregates (CLEA) in enzyme improvement - a review. Biocatalysis 1, 166-177. doi: 10.1515/boca-2015-0012

Vinita, Nirala, N. R., Tiwari, M., and Prakash, R. (2018). A nanoporous palladium(II) bridged coordination polymer acting as a peroxidase mimic in a method for visual detection of glucose in tear and saliva. Microchim. Acta 185, 1-10. doi: 10.1007/s00604-018-2776-8

Vishwanath, S. K., Watson, C. R., Huang, W., Bachas, L. G., and Bhattacharyya, D. (1997). Kinetic studies of site-specifically and randomly immobilized alkaline phosphatase on functionalized membranes. J. Chem. Technol. Biotechnol. 68, 294-302. doi: 10.1002/(sici)1097-4660(199703)68:3<294::aid-jctb637>3.0.co; $2-\mathrm{h}$

Wang, L., Zeng, Y., Shen, A., Fu, Y., Zeng, L., and Hu, J. (2016). Facile and controllable synthesis of triplex Au@Ag-Pt@infinite coordination polymer core-shell nanoparticles for highly efficient immobilization of enzymes and enhanced electrochemical biosensing activity. RSC Adv. 6, 86025-86033. doi: 10.1039/c6ra15293g

Wang, Q., Cui, J., Li, G., Zhang, J., Li, D., Huang, F., et al. (2014). Laccase immobilized on a pan/adsorbents composite nanofibrous membrane for catechol treatment by a biocatalysis/adsorption process. Molecules 19, 33763388. doi: 10.3390/molecules 19033376

Wang, Q., Peng, L., Du, Y., Xu, J., Cai, Y., Feng, Q., et al. (2013). Fabrication of hydrophilic nanoporous PMMA/O-MMT composite microfibrous membrane and its use in enzyme immobilization. J. Porous Mater. 20, 457-464. doi: 10. 1007/s10934-012-9615-9

Wang, S., Su, P., Ding, F., and Yang, Y. (2013). Immobilization of cellulase on polyamidoamine dendrimer-grafted silica. J. Mol. Catal. B Enzym. 89, 35-40. doi: 10.1016/j.molcatb.2012.12.011

Wang, X., Lu, X., Wu, L., and Chen, J. (2015). 3D metal-organic framework as highly efficient biosensing platform for ultrasensitive and rapid detection of bisphenol A. Biosens. Bioelectron. 65, 295-301. doi: 10.1016/j.bios.2014.10.010

Wang, Y., and Wu, C. (2018). Site-specific conjugation of polymers to proteins. Biomacromolecules 19, 1804-1825. doi: 10.1021/acs.biomac.8b0 0248

Wang, Z., Liu, T., Asif, M., Yu, Y., Wang, W., Wang, H., et al. (2018). Rimelike structure-inspired approach toward in situ-oriented self-assembly of hierarchical porous mof films as a sweat biosensor. ACS Appl. Mater. Interfaces 10, 27936-27946. doi: 10.1021/acsami.8b07868

Wang, Z. G., Wang, J. Q., and Xu, Z. K. (2006). Immobilization of lipase from Candida rugosa on electrospun polysulfone nanofibrous membranes by adsorption. J. Mol. Catal. B Enzym. 42, 45-51. doi: 10.1016/j.molcatb.2006.06. 004

Watanabe, F., Kubo, T., Kaya, K., and Hosoya, K. (2009). Novel separation medium spongy monolith for high throughput analyses. J. Chromatogr. A 1216, 7402-7408. doi: 10.1016/j.chroma.2009.06.054

Wei, Z., Fan, P., Jiao, Y., Wang, Y., Huang, Y., and Liu, Z. (2020). Integrated microfluidic chip for on-line proteome analysis with combination of denaturing and rapid digestion of protein. Anal. Chim. Acta 1102, 1-10. doi: 10.1016/j.aca. 2020.01.025

Weltz, J. S., Kienle, D. F., Schwartz, D. K., and Kaar, J. L. (2019). Dramatic increase in catalytic performance of immobilized lipases by their stabilization on polymer brush supports. ACS Catal. 9, 4992-5001. doi: 10.1021/acscatal. $9 \mathrm{~b} 01176$

Wen, L., Gao, A., Cao, Y., Svec, F., Tan, T., and Lv, Y. (2016a). Layer-by-layer assembly of metal-organic frameworks in macroporous polymer monolith and their use for enzyme immobilization. Macromol. Rapid Commun. 37, 551-557. doi: 10.1002/marc.201500705

Wen, L., Tan, X., Sun, Q., Svec, F., and Lv, Y. (2016b). "Smart" molecularly imprinted monoliths for the selective capture and easy release of proteins. J. Sep. Sci. 39, 3267-3273. doi: 10.1002/jssc.201600576

Wilson, L., Illanes, A., Abián, O., Pessela, B. C. C., Fernández-Lafuente, R., and Guisán, J. M. (2004). Co-aggregation of penicillin G acylase and polyionic polymers: an easy methodology to prepare enzyme biocatalysts stable in organic media. Biomacromolecules 5, 852-857. doi: 10.1021/bm0343895

Wright, T. A., Page, R. C., and Konkolewicz, D. (2019). Polymer conjugation of proteins as a synthetic post-translational modification to impact their stability and activity. Polym. Chem. 10, 434-454. doi: 10.1039/c8py01399c

Wu, X., Yang, C., and Ge, J. (2017). Green synthesis of enzyme/metal-organic framework composites with high stability in protein denaturing solvents. Bioresour. Bioprocess. 4:24. doi: 10.1186/s40643-017-0154-8

Wu, X., Yue, H., Zhang, Y., Gao, X., Li, X., Wang, L., et al. (2019). Packaging and delivering enzymes by amorphous metal-organic frameworks. Nat. Commun. 10, 1-8. doi: 10.1038/s41467-019-13153-x

Xiong, M., Zhang, M., Liu, Q., Yang, C., Xie, Q., Ke, G., et al. (2020). Biomineralized nanoparticles enable an enzyme-assisted DNA signal amplification in living cells. Chem. Commun. 56, 2901-2904. doi: 10.1039/c9cc09503a

Yakup Arica, M., and Bayramoglu, G. (2004). Reversible immobilization of tyrosinase onto polyethyleneimine-grafted and $\mathrm{Cu}(\mathrm{II})$ chelated poly(HEMAco-GMA) reactive membranes. J. Mol. Catal. B Enzym. 27, 255-265. doi: 10. 1016/j.molcatb.2003.12.006

Yamaguchi, H., Miyazaki, M., Asanomi, Y., and Maeda, H. (2011). Poly-lysine supported cross-linked enzyme aggregates with efficient enzymatic activity and high operational stability. Catal. Sci. Technol. 1, 1256-1261. doi: 10.1039/ clcy00084e

Yan, M., Du, J., Gu, Z., Liang, M., Hu, Y., Zhang, W., et al. (2010). A novel intracellular protein delivery platform based on single-protein nanocapsules. Nat. Nanotechnol. 5, 48-53. doi: 10.1038/nnano.2009.341

Yan, M., Ge, J., Liu, Z., and Ouyang, P. (2006). Encapsulation of single enzyme in nanogel with enhanced biocatalytic activity and stability. J. Am. Chem. Soc. 128, 11008-11009. doi: 10.1021/ja064126t

Yang, X., Tang, Q., Jiang, Y., Zhang, M., Wang, M., and Mao, L. (2019). Nanoscale ATP-responsive zeolitic imidazole framework-90 as a general platform for cytosolic protein delivery and genome editing. J. Am. Chem. Soc. 141, 37823786. doi: 10.1021/jacs.8b11996

You, Y., Xu, D., Pan, X., and Ma, X. (2019). Self-propelled enzymatic nanomotors for enhancing synergetic photodynamic and starvation therapy by selfaccelerated cascade reactions. Appl. Mater. Today 16, 508-517. doi: 10.1016/j. apmt.2019.07.008

Yu, A., Wang, Y., Barlow, E., and Caruso, F. (2005). Mesoporous silica particles as templates for preparing enzyme-loaded biocompatible microcapsules. $A d v$. Mater. 17, 1737-1741. doi: 10.1002/adma.200402045

Yuan, J., Gaponik, N., and Eychmüller, A. (2012). Application of polymer quantum dot-enzyme hybrids in the biosensor development and test paper fabrication. Anal. Chem. 84, 5047-5052. doi: 10.1021/ac300714j

Zdarta, J., Jankowska, K., Bachosz, K., Kijeńska-Gawrońska, E., ZgołaGrześkowiak, A., Kaczorek, E., et al. (2019a). A promising laccase immobilization using electrospun materials for biocatalytic degradation of tetracycline: effect of process conditions and catalytic pathways. Catal. Today. 348, 127-136. doi: 10.1016/j.cattod.2019.08.042

Zdarta, J., Jankowska, K., Wyszowska, M., Kijeńska-Gawrońska, E., ZgołaGrześkowiak, A., Pinelo, M., et al. (2019b). Robust biodegradation of naproxen and diclofenac by laccase immobilized using electrospun nanofibers with enhanced stability and reusability. Mater. Sci. Eng. C 103:109789. doi: 10.1016/ j.msec.2019.109789 
Zdarta, J., Meyer, A., Jesionowski, T., Pinelo, M., Zdarta, J., Meyer, A. S., et al. (2018). A general overview of support materials for enzyme immobilization: characteristics, properties, practical utility. Catalysts 8:92. doi: 10.3390/ catal 8020092

Zhang, A., Meng, X., Bao, C., and Zhang, Q. (2020). In situ synthesis of proteinloaded hydrogels via biocatalytic ATRP. Polym. Chem. 11, 1525-1532. doi: 10.1039/c9py01815h

Zhang, C., Dong, X., Guo, Z., and Sun, Y. (2018). Remarkably enhanced activity and substrate affinity of lipase covalently bonded on zwitterionic polymergrafted silica nanoparticles. J. Coll. Interf. Sci. 519, 145-153. doi: 10.1016/j.jcis. 2018.02.039

Zhang, Y., Park, K. Y., Suazo, K. F., and Distefano, M. D. (2018). Recent progress in enzymatic protein labelling techniques and their applications. Chem. Soc. Rev. 47, 9106-9136. doi: 10.1039/c8cs00537k

Zhang, C., Wang, X., Hou, M., Li, X., Wu, X., and Ge, J. (2017). Immobilization on metal-organic framework engenders high sensitivity for enzymatic electrochemical detection. ACS Appl. Mater. Interf. 9, 13831-13836. doi: 10. 1021/acsami.7b02803

Zhang, J., He, M., Nie, C., He, M., Pan, Q., Liu, C., et al. (2019a). Biomineralized metal-organic framework nanoparticles enable enzymatic rolling circle amplification in living cells for ultrasensitive microRNA imaging. Anal. Chem. 91, 9049-9057. doi: 10.1021/acs.analchem.9b01343

Zhang, J., Huang, X., Zhang, L., Si, Y., Guo, S., Su, H., et al. (2019b). Layer-by-layer assembly for immobilizing enzymes in enzymatic biofuel cells. Sustain. Energy Fuels 4, 68-79. doi: 10.1039/c9se00643e

Zhang, Y., Wang, Y., Tang, Y., Li, R., and Ji, Y. (2019). An online immobilized pepsin microreactor based on polymer monoliths for screening inhibitors from natural products. Anal. Methods 11, 2465-2472. doi: 10.1039/c9ay00343f

Zhang, P., Sun, F., Tsao, C., Liu, S., Jain, P., Sinclair, A., et al. (2015). Zwitterionic gel encapsulation promotes protein stability, enhances pharmacokinetics, and reduces immunogenicity. Proc. Natl. Acad. Sci. U.S.A. 112, 12046-12051. doi: 10.1073/pnas.1512465112

Zhang, Y., Ge, J., and Liu, Z. (2015). Enhanced activity of immobilized or chemically modified enzymes. ACS Catal. 5, 4503-4513. doi: 10.1021/acscatal. 5 b00996

Zhang, P., Wang, Q., Zhang, J., Li, G., and Wei, Q. (2014). Preparation of amidoxime-modified polyacrylonitrile nanofibers immobilized with laccase for dye degradation. Fibers Polym. 15, 30-34. doi: 10.1007/s12221-0140030-5

Zhao, S., Zou, Y., Liu, X., and Zhang, H. (2019). Ecofriendly construction of enzyme reactor based on three-dimensional porous cryogel composites. Chem. Eng. J. 361, 286-293. doi: 10.1016/j.cej.2018.12.101

Zhao, X., Fan, P.-R., Mo, C.-E., Huang, Y.-P., and Liu, Z.-S. (2020). Green synthesis of monolithic enzyme microreactor based on thiol-ene click reaction for enzymatic hydrolysis of protein. J. Chromatogr. A 1611:460618. doi: 10.1016/ j.chroma.2019.460618

Zheng, G., Liu, S., Zha, J., Zhang, P., Xu, X., Chen, Y., et al. (2019). Protecting enzymatic activity via zwitterionic nanocapsulation for the removal of phenol compound from wastewater. Langmuir 35, 1858-1863. doi: 10.1021/acs. langmuir.8b02001

Zhong, X., Qian, Y., Huang, J., Yang, D., Deng, Y., and Qiu, X. (2016). Fabrication of lignosulfonate vesicular reverse micelles to immobilize horseradish peroxidase. Ind. Eng. Chem. Res. 55, 2731-2737. doi: 10.1021/acs.iecr.5b 04939

Zhou, Z., Ju, X., Zhou, M., Xu, X., Fu, J., and Li, L. (2019). An enhanced ionic liquid-tolerant immobilized cellulase system via hydrogel microsphere for improving in situ saccharification of biomass. Bioresour. Technol. 294:122146. doi: 10.1016/j.biortech.2019.122146

Zhu, L. L., Zhu, C. T., Xiong, M., Jin, C. Q., Sheng, S., Wu, F. A., et al. (2019). Enzyme immobilization on photopatterned temperature-response poly (Nisopropylacrylamide) for microfluidic biocatalysis. J. Chem. Technol. Biotechnol. 94, 1670-1678. doi: 10.1002/jctb.5946

Conflict of Interest: The authors declare that the research was conducted in the absence of any commercial or financial relationships that could be construed as a potential conflict of interest.

Copyright (c) 2020 Rodriguez-Abetxuko, Sánchez-deAlcázar, Muñumer and Beloqui. This is an open-access article distributed under the terms of the Creative Commons Attribution License (CC BY). The use, distribution or reproduction in other forums is permitted, provided the original author(s) and the copyright owner(s) are credited and that the original publication in this journal is cited, in accordance with accepted academic practice. No use, distribution or reproduction is permitted which does not comply with these terms. 